\title{
Stratigraphic continuity and early deformation of the central part of the Coppin Gap Greenstone Belt, Pilbara, Western Australia
}

\author{
Sjoukje T. de Vries ${ }^{\mathrm{a}, *}$, Wouter Nijman ${ }^{\mathrm{a}}$, Jan R. Wijbrans ${ }^{\mathrm{b}}$, David R. Nelson ${ }^{\mathrm{c}}$ \\ a Department of Earth Sciences, Utrecht University, Budapestlaan 4, 3584 CD Utrecht, The Netherlands \\ ${ }^{\mathrm{b}}$ Faculty of Earth and Life Sciences, Free University of Amsterdam, De Boelelaan 1085, 1081 HV Amsterdam, The Netherlands \\ c John de Laeter Centre of Mass Spectrometry, Department of Applied Physics, Curtin University of Technology, \\ GPO Box U1987, Perth, WA 6845, Australia
}

Received 22 December 2004; received in revised form 9 January 2006; accepted 10 January 2006

\begin{abstract}
This article focuses on the discrepancy between the often advocated stratigraphic continuity of greenstone belts in the Pilbara Craton (Australia) on the one hand, and the observations of syndepositional deformation and other tectonic disturbance on the other hand. The Coppin Gap Greenstone Belt of the East Pilbara consists predominantly of mafic, intermediate and felsic rocks, with minor amounts of silicified sedimentary rocks of the early Archaean Warrawoona Group. Several well-defined zones subparallel to the bedding show intense brittle to ductile deformation, testifying to differential movements of the tectono-stratigraphic slices they delimit. These deformation zones were at least partly related to west-block-down normal faults and accommodated upper block to the west transport. However, new U-Pb zircon dates, geochemical analyses and detailed field observations show that the overall stratigraphic succession in the Coppin Gap Greenstone Belt has not been fundamentally disturbed.

The normal faults occur in several irregularly superposed arrays of km-spaced faults, part of which were active during deposition. Normal faults also occur throughout the entire belt. Combined, the early deformation structures indicate east-west extension over a minimum period of $20 \mathrm{Ma}$, from $\sim 3469 \mathrm{Ma}$ onwards. Likely, the extension took place over an even longer period of time, during much of the time of deposition of the Warrawoona Group, from 3490 Ma onwards. Syndepositional extension of the Warrawoona Group was geometrically unrelated to the doming of granitoid batholiths.

Surficial (i.e. uppermost crustal) gravitational collapse during or shortly after deposition may have caused the apparent contradictory co-existence of deformation zones and stratigraphic continuity. Although the deformation has not caused major disruptions of the stratigraphic succession, the precision of the U-Pb SHRIMP ages is insufficient to rule out excisions or duplications of stratigraphy on the order of a few million years.
\end{abstract}

(C) 2006 Elsevier B.V. All rights reserved.

Keywords: Early Archaean; Warrawoona Group; Duffer Formation; Early extension; Normal growth faulting; Geochronology; Pilbara Craton

\section{Introduction}

The nature of the tectonic regime during the Archaean era is still controversial. There is debate about whether a

\footnotetext{
* Corresponding author. Tel.: +612628348212.

E-mail address: stdevries@geo.uu.nl (S.T. de Vries).
}

plate tectonic mechanism operated during that time (e.g. De Wit, 1998; Hamilton, 1998). Directly related is the discussion about the degree of disruption of the original stratigraphic succession in early Archaean greenstone belts. Nijman et al. (1998b) and Van Haaften and White (1998) suggested that duplications of parts of the stratigraphy of an early Archaean greenstone belt in the Pilbara (Australia) might have taken place (the Coppin Gap 
Greenstone Belt and its westward extension towards the Marble Bar Belt). In contrast, Van Kranendonk et al. (2001a) and Beintema (2003) concluded that there is little disruption and that the succession is predominantly coherent.

The objective of this paper, which focuses on the Coppin Gap Greenstone Belt (Fig. 1), is to characterise the earliest tectonic regime and its influence on the stratigraphic continuity of the volcano-sedimentary succession. Rocks in the Coppin Gap Greenstone Belt belong dominantly to the Warrawoona Group ( 3490-3346 Ma, Beintema, 2003; Nelson, 2001; Van Kranendonk et al., 2002) and the overlying Gorge Creek Group (as yet undated; e.g. Van Kranendonk et al., 2002). Nijman et al. (1998b) recognised a relationship between early deformation and clastic sedimentation in this greenstone belt. They described sediments that were deposited during late Warrawoona Group extension and subsequent Gorge Creek Group compression. The disruption of the stratigraphic succession by deformation zones was suggested and their position indicated, but their influence on the overall stratigraphic continuity remained unclear.

Later studies of the Coppin Gap Belt confirmed the importance of early extension along major shear zones in the easternmost part of the belt (Zegers et al., 2002) and recognised early extension accompanied by dolerite dyke intrusion during late Warrawoona Group time (Kloppenburg, 2003). From the adjacent Marble Bar Belt, Collins (1989) described intraformational folds, which were interpreted to be related to flank collapse along the rising Mt Edgar batholith. Beintema (2003) mentioned the syndepositional activity of normal faults within the stratigraphic top of the $\sim 3490$ Ma North Star Basalt in this belt.

For this study, the central part of the Coppin Gap Greenstone Belt (Figs. 1 and 2) was revisited. In this area, the Warrawoona Group obtains its maximum thickness of about $13 \mathrm{~km}$.

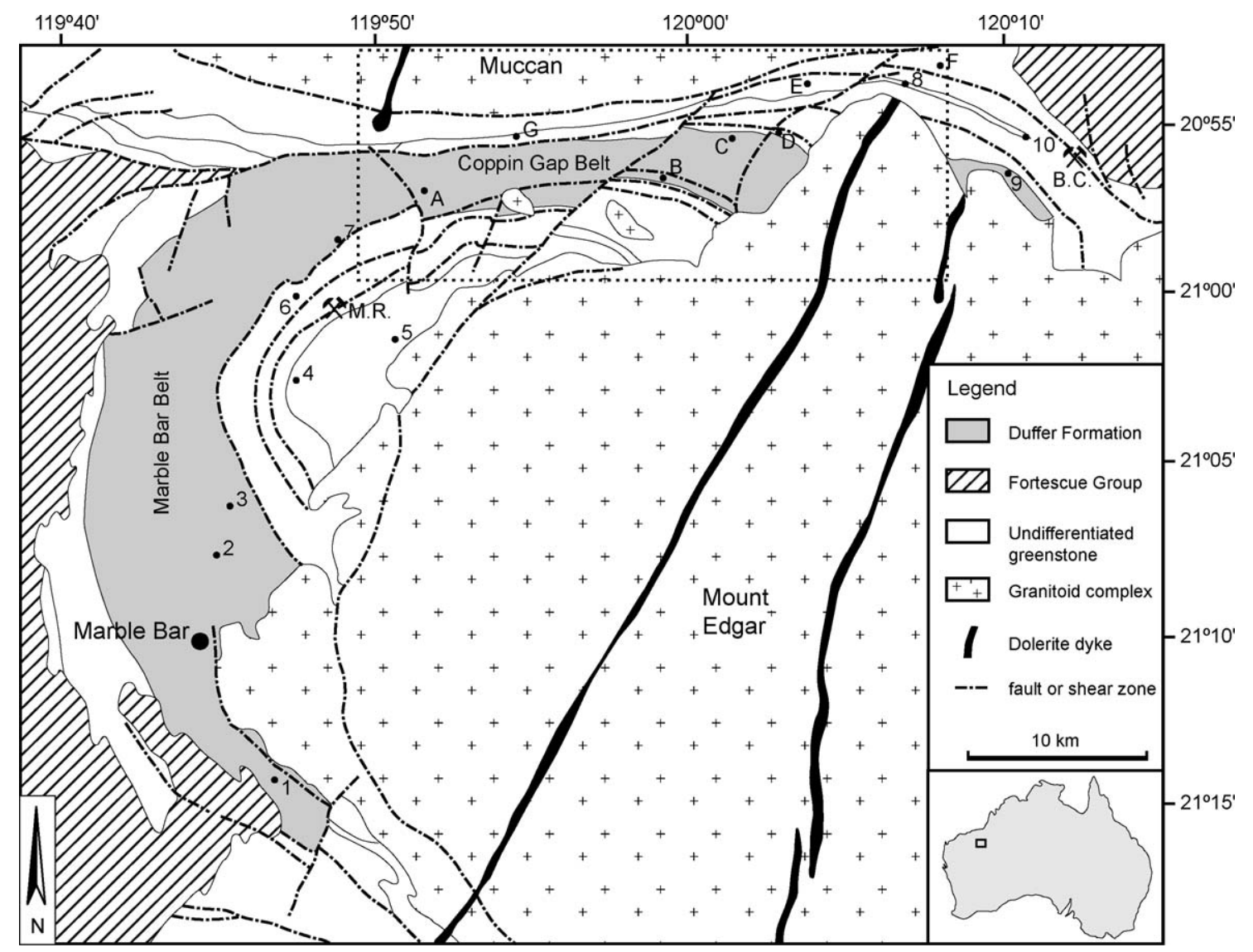

Fig. 1. Schematic geological map of the $\mathrm{N}-\mathrm{S}$ trending Marble Bar belt and the E-W trending Coppin Gap greenstone belt and surrounding granitoid complexes (modified after Nijman et al., 1998b; Van Haaften and White, 1998; Van Kranendonk et al., 2001b). Letters refer to new dates presented in this study, numbers refer to previously published dates of the Warrawoona Group in this area. Geochronology details and references in Table 2. M.R. = McPhee Reward mining area, B.C. $=$ Bamboo Creek mining area. Outlines of Fig. 2 indicated with dashed rectangle. 


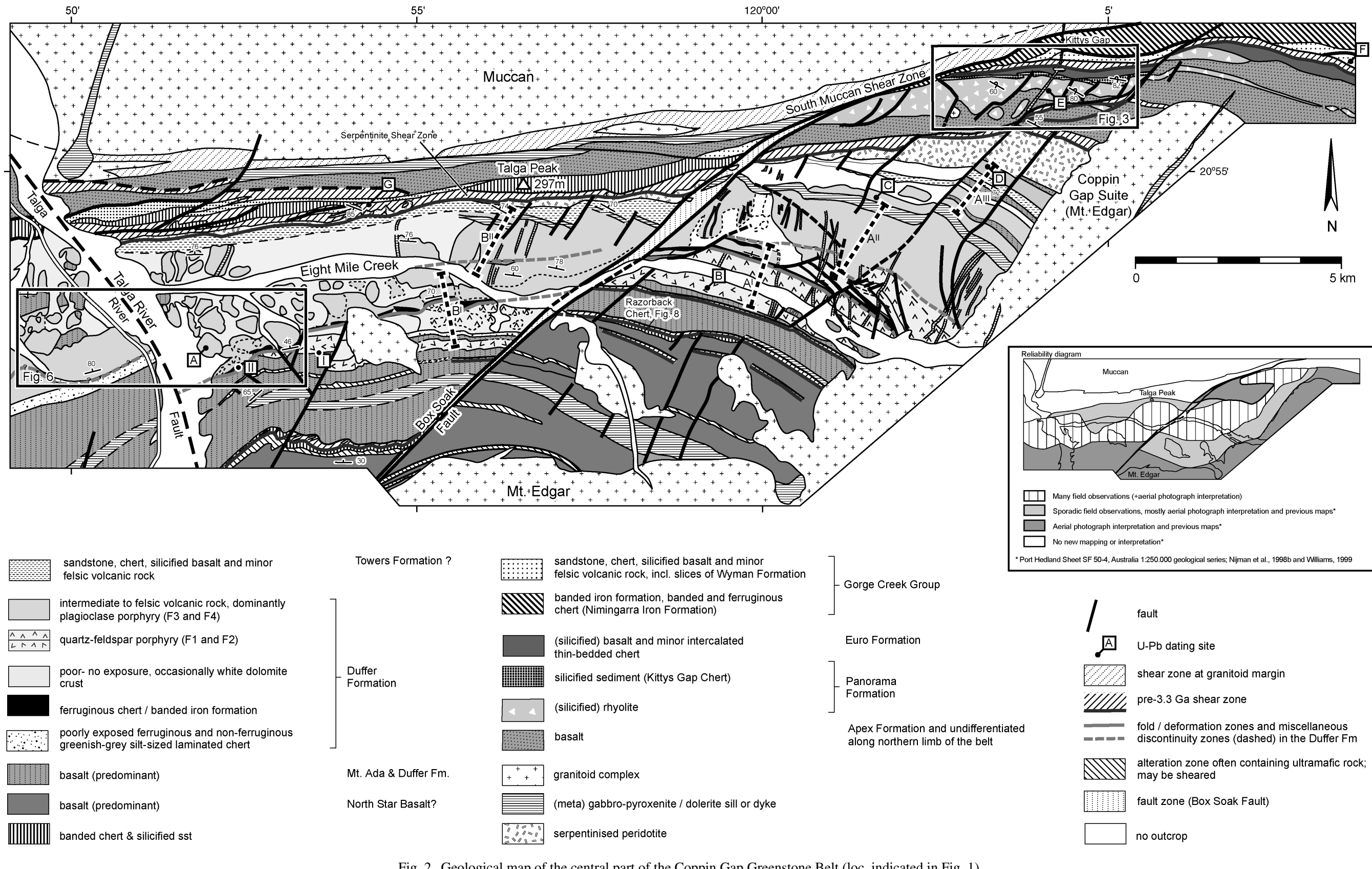

Fig. 2. Geological map of the central part of the Coppin Gap Greenstone Belt (loc. indicated in Fig. 1). 
Based on many new field observations, U-Pb SHRIMP dating and geochemical analyses, this study intends to provide insights into the tectonic regime during deposition of the Warrawoona Group and its influence on the continuity of the Warrawoona Group in the Coppin Gap Greenstone Belt.

\section{General geology of the central Coppin Gap Greenstone Belt}

The Coppin Gap Greenstone Belt, an east-west oriented greenstone belt situated between the Mt Edgar and Muccan Granitoid Complexes (Fig. 1), comprises a tightly folded synclinorium with a well-preserved southern limb and a sheared northern limb (Nijman et al., 1998b). Along the southern limb the bedding is oriented roughly east-west, the dips are near-vertical and the younging direction is to the north. From south to north the southern limb provides a cross-section through part of the early Archaean crust.

A major NE-SW oriented fault (the Box Soak Fault (BSF), after the abandoned Box Soak Well; Fig. 2), divides the area into eastern and western parts. The presence of a second major fault at high angles to bedding is inferred further westward, along the Talga River (Talga River Fault; Fig. 2). Deformation zones that are parallel, or at low angles, to bedding can be correlated across these faults.

The major part of the rocks along the southern limb of the syncline belong to the Warrawoona Group, which is, from base to top, subdivided into the North Star Basalt, McPhee, Mt. Ada, Duffer, Towers, Apex, Panorama, Euro Basalt and Wyman Formations (based on lithostratigraphic subdivisions by Van Kranendonk et al. (2002)). The most complete preservation of the Warrawoona Group stratigraphic succession is found east of the BSF.

Felsic rocks in the Coppin Gap Greenstone Belt belong dominantly to the Duffer and Panorama Formations. The Duffer Formation forms a major part of the Warrawoona Group in the Coppin Gap Greenstone Belt (Fig. 2). East of the BSF (Fig. 2), the outcrop of the Duffer Formation is rather uniform. West of the BSF, particularly in the vicinity of the Talga River, the map view of the Duffer Formation changes. Here, well-preserved ovoid outcrops of Duffer Formation are surrounded by poorly to non-exposed areas (with occasional dolomite crusts). The Panorama Formation is exposed in the northeastern part of the Coppin Gap Greenstone Belt (south of Kittys Gap, Fig. 2).

The Warrawoona Group is unconformably overlain by sedimentary rocks of the Gorge Creek Group.
Regional metamorphism is low-grade, except adjacent to the granitoid complexes (cf. Williams, 1999) where the metamorphic grade is commonly higher.

\section{Stratigraphy of the Coppin Gap Greenstone Belt}

Most new field observations in the central part of the Coppin Gap Greenstone Belt (Fig. 2) concern the Duffer Formation, its contact with the underlying Mt Ada Basalt and the deformation zones it contains. Also, the Panorama Formation in the Kittys Gap area has been mapped in detail (Fig. 3).

\subsection{New data on the stratigraphy}

\subsubsection{Duffer Formation}

The Duffer Formation will be described on the basis of two composite stratigraphic columns, on the east and west side of the BSF, respectively (A and B, Figs. 2 and 4). The composing stratigraphic fragments (F1-F4) are bounded by deformation zones and can be correlated across the BSF (Fig. 4). Additional details on the lithology are given in Table 1.

Fragment 1 (F1). The lowermost unit of the Duffer Formation consists of an up to $\sim 300 \mathrm{~m}$ thick quartzplagioclase porphyry ${ }^{1}$ (Fig. 4). U-Pb SHRIMP analysis of this unit on the eastern side of the BSF has yielded a date of $3465 \pm 4 \mathrm{Ma}$ (all uncertainties cited herein are at the $95 \%$ confidence level unless otherwise indicated; loc. B, Figs. 1 and 2; details on dating in Fig. 5b, Table 2 and Appendix A). The upper part of $\mathrm{F} 1$ is poorly exposed and consists mainly of small outcrops and debris of finegrained mafic rocks and chert. Locally, the succession ends with strongly foliated, very fine-grained rocks that have been altered to carbonate and occasionally contain quartz lenses (discussed below).

Fragment 2 (F2). The next fragment of the Duffer Formation succession consists of $\sim 200-300 \mathrm{~m}$ of massive, silicified dacite with abundant plagioclase phenocrysts.

Fragment 3 (F3). F3 is a $\sim 200 \mathrm{~m}$ thick unit of felsic rocks, including agglomerate and plagioclase porphyry, sandwiched between two layers of banded iron-formation (BIF). The basal BIF unit (BIF 1) varies in thickness between 0 and $100 \mathrm{~m}$ and has been folded

\footnotetext{
${ }^{1}$ In this article, the term porphyry is used for igneous rocks that are characterised by mm-sized phenocrysts hosted by abundant very fine-grained groundmass.
} 
along most of its exposure. The second BIF interval (BIF 2), above the felsic unit, is only exposed in small outcrops, which generally show a pronounced beddingparallel cleavage. East of column A, the rock succession has been complicated by intraformational tectonics (see Section 4.2).

Fragment 4 (F4). F4 comprises the main volume of felsic rocks of the Duffer Formation within the belt. The rocks mainly consist of massive, dacitic to andesitic plagioclase porphyry and generally lack stratification. Agglomerate occurs locally abundantly throughout the lower two-third of the main felsic unit. In the central and eastern part of the area, the top of F4 is intruded by a (meta)gabbro-pyroxenite sill (Fig. 2). SHRIMP U-Pb dating of the felsic rocks above this sill (loc. C, Fig. 2) yielded a date of $3465 \pm 4 \mathrm{Ma}$ (Fig. $5 \mathrm{c}$ and Appendix A).

Westward correlation. A quartz-plagioclase porphyry in one of the lowermost isolated outcrops immediately east of the Talga River (loc. A, Fig. 2), was dated at $3464 \pm 2 \mathrm{Ma}$ (Fig. 5a and Appendix A).

The lowermost felsic unit of the Duffer Formation west of the Talga River Fault is $\sim 860$ m thick and consists mainly of plagioclase porphyry and agglomerate. In thickness, lithology and aerial photograph character this corresponds with the main felsic unit (F4) of columns A and B. Near its base, the felsic unit contains pumice fragments, which also occur in the Duffer Formation immediately east of the Talga River (loc. in Fig. 6). This single pumice-bearing level was used to correlate the sections on either side of the Talga River. The intermediate rocks of the Duffer Formation west of the Talga River are underlain by an interval that contains greenish-grey and ferruginous, silt-sized, finely laminated chert. Further to the west, just outside the map area of Fig. 6, this unit contains locally folded BIF, comparable to that of unit F3. The quartz-plagioclase porphyry (F1) and the massive dacite (F2) are absent west of the Talga River (see also Section 4.2).

\subsubsection{Warrawoona Group chert unit below the Duffer Formation}

The oldest preserved chert unit of the Warrawoona Group east of the BSF, the Razorback Chert (informal name after the Box Soak Razorback, the topographical ridge formed by the chert), is located approximately $1 \mathrm{~km}$ below the Duffer Formation, above a succession of basalts and below a major deformation zone in mafic rocks (see Section 4.1.2). The (grey-)black and white banded chert occasionally grades into grey-green massive chert and has a maximum thickness of $\sim 30 \mathrm{~m}$ near the eastern part of the outcrop. Eastward and westward, the thickness diminishes and the outcrop becomes poorer (Fig. 7).

West of the BSF, there is only one chert unit present below the Duffer Formation, which may be the westward extension of the Razorback Chert (see Section 4.2.3).

\subsubsection{Warrawoona Group rocks overlying the Duffer Formation}

The dominantly felsic rocks of the Duffer Formation are overlain by poorly exposed, black-green, finegrained, altered (chloritised and serpentinised) massive basalts. They are overlain by very poorly exposed, wellbedded, grey to reddish, siltstone to fine-grained sandstone, which are in places silicified. West of the BSF, the basalts and silty sedimentary rocks are truncated by a serpentinised peridotite sill, which is bounded by shear zones in most of the area (see Fig. 2 and Section 4.2).

Near the contact with the Coppin Gap Suite of the Mt Edgar Granitoid Complex (Fig. 2, segment $\mathrm{A}^{\mathrm{III}}$ ), the Warrawoona Group succession on top of these siltstones has been preserved. After an unexposed interval of $\sim 50 \mathrm{~m}$, this succession begins with a unit that dominantly consists of altered, light-grey andesite (loc. D, Fig. 2), which was dated at $3459 \pm 2 \mathrm{Ma}$ (Fig. 5d and Appendix A). The interval is truncated at the top by a serpentinised peridotite sill, which has been affected by shear deformation along its boundaries and internally (see Section 4.2). The overlying succession consists of a severely chloritised basalt (Apex Formation according to Williams (1999)) that is in turn overlain by felsic volcanic and volcaniclastic rocks (Fig. 3).

The felsic rocks consist of altered and in places flow-banded quartz-feldspar porphyries (rhyolite to rhyodacite) and minor amounts of agglomerate and other pyroclastic rocks. U-Pb zircon dating of a sample from the base of the quartz-feldspar porphyry (loc. E, Fig. 2) yielded a date of $3446 \pm 5 \mathrm{Ma}$ (Fig. 5e and Appendix A). The felsic rocks are capped by silicified sedimentary rocks. Together, this assemblage forms the Kittys Gap volcano-sedimentary complex of the Panorama Formation (KG-vsc; for details on the sedimentology of this complex, see De Vries et al., 2006). The KGvsc is overlain by serpentinised and carbonate-altered massive basalt, which locally shows hyaloclastic brecciation and columnar jointing. These rocks belong to the Euro Formation (Williams, 1999), which is here truncated by the Bamboo Creek Shear Zone (BCSZ, Fig. 3; Nijman et al., 1998b; Williams, 1999; the westward extension of the BCSZ described by Zegers et al. (2002)). 


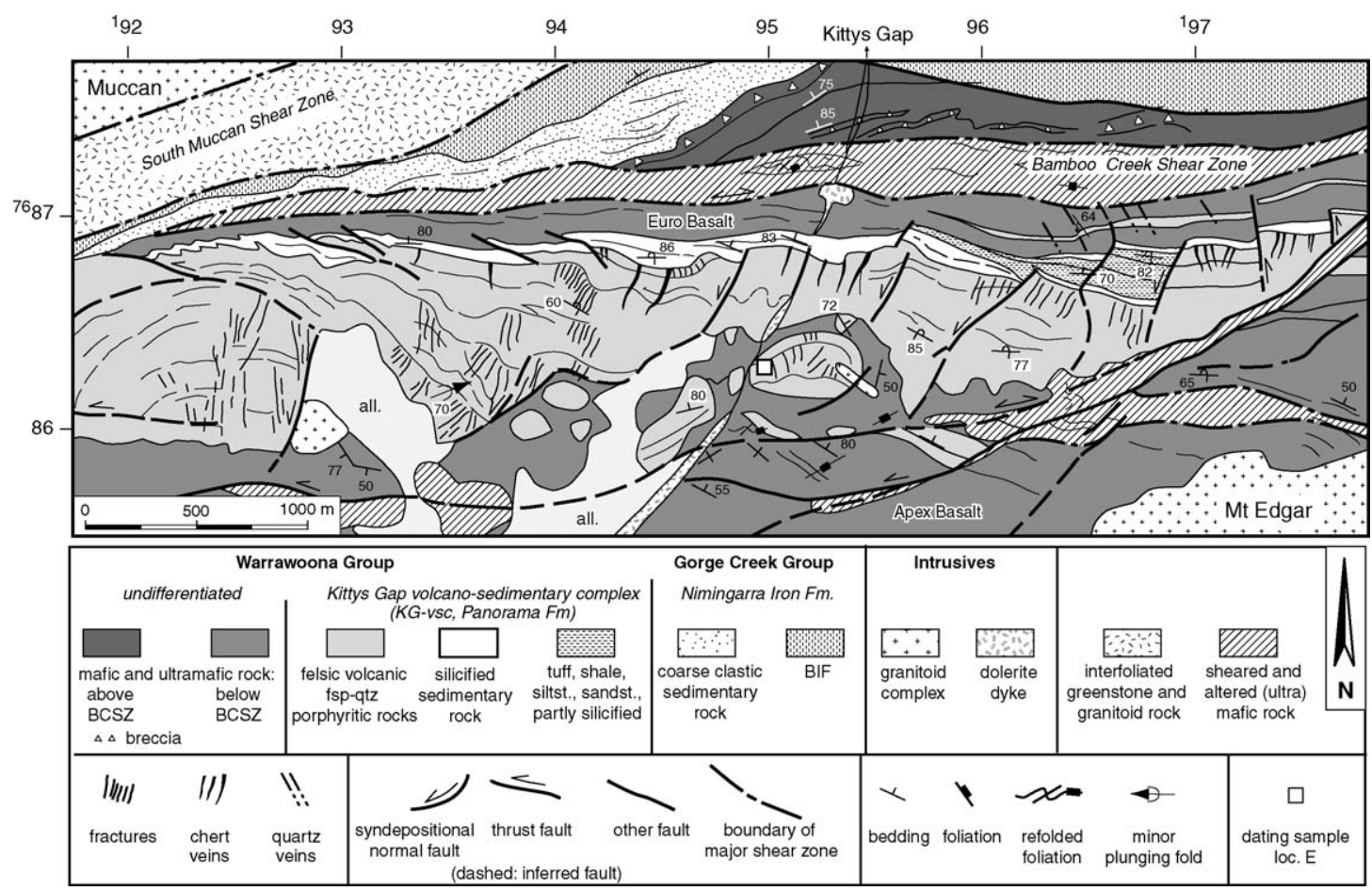

Fig. 3. Geological map of the normal-faulted Kittys Gap volcano-sedimentary complex (Panorama Formation) between mafic and ultramafic rocks of the Apex Formation (below) and the Euro Formation (above). The Euro Formation is cut by the Bamboo Creek Shear Zone (BCSZ). Hanging-wall blocks in the western part of the fault array have been rotated and deformed into rollover anticlines. Sediment wedges at the top of the complex in that area have been thrust over each other in westward direction. Eastward, the sediment wedges tend to onlap the previous ones. Location indicated in Fig. 2. Grid numbers refer to Australian Map Grid zone 51.

\subsubsection{Succession overlying the Bamboo Creek Shear Zone}

The rocks above the Bamboo Creek Shear Zone and the shear-bounded serpentinised peridotite west of the BSF have not been studied in detail. They comprise slices of the Warrawoona and Gorge Creek Groups, which are in turn unconformably overlain by younger sedimentary rocks of the Gorge Creek Group (Nijman et al., 1998b; Williams, 1999). Two new U-Pb zircon dates have been obtained from these rocks to better constrain the timing of events in the Coppin Gap Greenstone Belt:

(1) a silicified, banded sandstone $\sim 6 \mathrm{~km}$ east of Kittys Gap (loc. F, Fig. 2) from a unit mapped as Gorge Creek Group (Williams, 1999) contains detrital zircons that were dated at $3459 \pm 4 \mathrm{Ma}$ (Fig. 5f and Appendix A). Discordant analyses from the same sample that indicate younger dates are interpreted to be of analysis sites that have lost radiogenic $\mathrm{Pb}$. The date of $3459 \pm 4 \mathrm{Ma}$ indicated by 10 pooled analyses is interpreted as the maximum age of deposition of the banded cherts (see Appendix A).
(2) A feldspar porphyry from a zone of deformed and discontinuous rock units above the shear-bounded serpentinised peridotite (loc. G, Fig. 2), previously mapped as belonging to the 'P-unit' (Nijman et al., 1998b), is now placed in the Wyman Formation based on its $\mathrm{U}-\mathrm{Pb}$ zircon age of $3318 \pm 4 \mathrm{Ma}$ (Fig. $5 \mathrm{~g}$ and Appendix A).

\subsection{New geochemical data}

Selected Rare Earth Element (REE) diagrams (Fig. 8) are here presented to illustrate the difference between the felsic volcanic rocks of the Duffer and Panorama Formations. The REE patterns show that dacites from the lower part of the Duffer Formation are characterised by a Eu-anomaly and show the highest enrichment in the heavy REE's (Gd-Lu, Fig. 8a). Duffer Formation andesites (from the middle and upper part of the main felsic Duffer Formation in F4) have lower overall REE abundances and do not have a negative Eu-anomaly (Fig. 8b). Their normalised La/Yb ratio's overlap with those measured for the dacites, but show a broader range (Fig. 8c). The Panorama Formation rhyodacites also have 


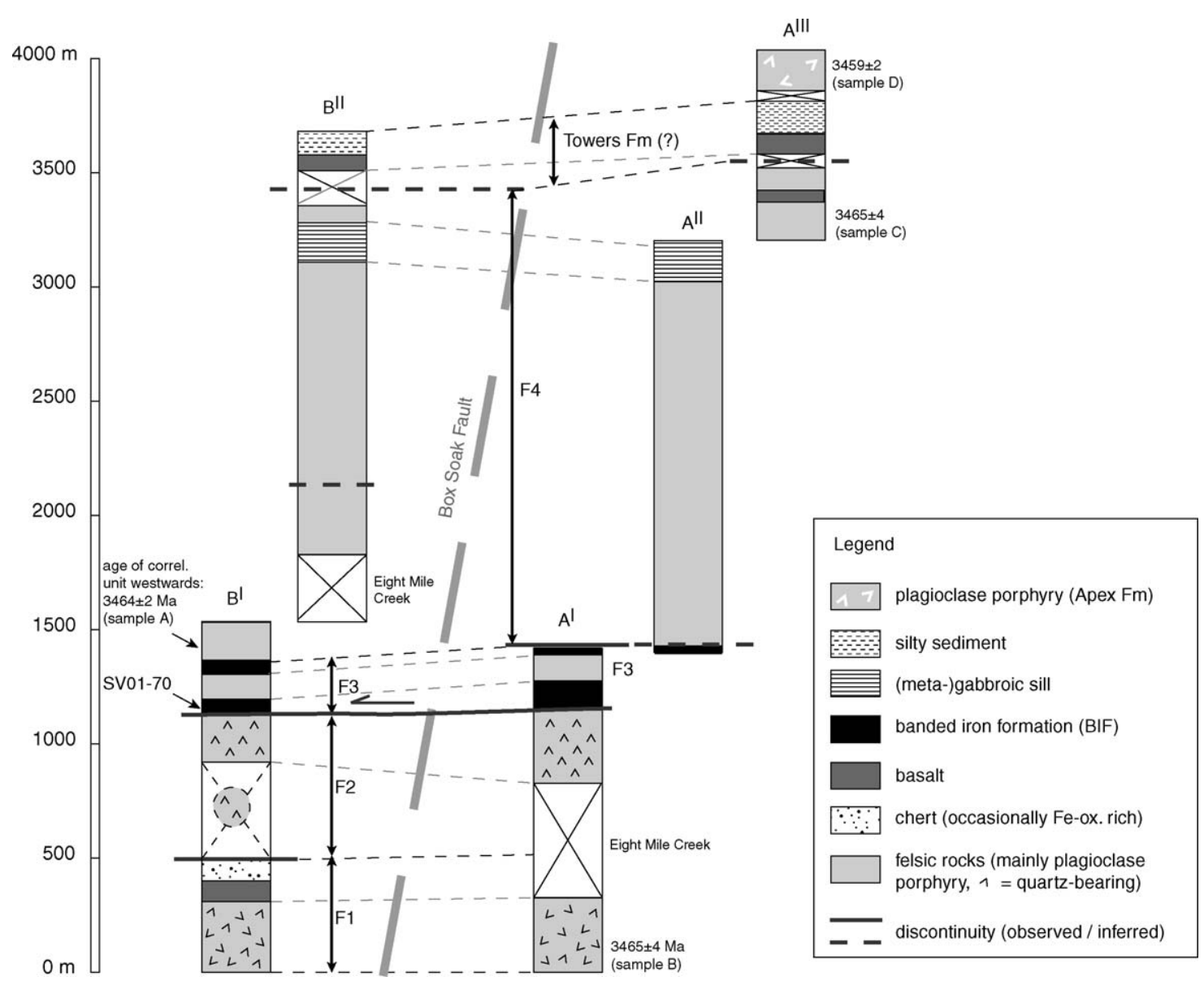

Fig. 4. Schematic composite lithological columns through the Duffer and Towers Formations east (column A) and west (column B) of the Box Soak Fault. Locations of sections are indicated in Fig. 2. 'Fragments' of Duffer stratigraphy are number F1-F4.

lower REE abundances than dacites from the Duffer Formation, and show no Eu-anomalies. Overlap with the range measured for the Duffer Formation andesites is substantial.

\subsection{Interpretation of the Warrawoona Group stratigraphy}

\subsubsection{Duffer Formation}

It is difficult to distinguish whether the massive quartz-and plagioclase-porphyritic rocks that make up the bulk of the Duffer Formation were emplaced as lavas or as shallow intrusives. However, their interbedding with agglomerates and thin ash layers, and the occasional occurrence of columnar jointing, suggest that they have an extrusive origin. This abundance of felsic to intermediate lavas indicates proximal, near-vent deposition. Nevertheless, no evidence for feeder dykes or eruptive necks has been found in the study area (cf. DiMarco and Lowe, 1989b for other locations in the East Pilbara granite-greenstone terrane). The presence of ash and the incorporation of pumice-bearing layers indicate that volcanism was occasionally explosive. The generally well bedded to laminated character of the ash layers suggest that deposition took place in a quiet, subaqueous environment. Field observations and geochemistry (Fig. 8) show that the nature of volcanism changed from dacitic to more andesitic from base to top within the Duffer Formation. The change to slightly more mafic volcanism is also indicated by the occasional intercalation of pillow basalts in the top of the Duffer Formation. Furthermore, the pillow basalts point to subaqueous deposition. The ages of the different felsic volcanic rock units indicate that the bulk of the Duffer Formation in the study area was deposited in less than $10 \mathrm{Ma}$, between 3469 and $3461 \mathrm{Ma}$ (Fig. 9). The date obtained for the felsic unit near the stratigraphic top of the Duffer Formation (3465 $\pm 4 \mathrm{Ma}$; sample C, Fig. 2) is similar to that for quartz-plagioclase porphyry unit $\mathrm{F} 1$ from the base of the Duffer Formation (3465 \pm 4 Ma, sample B, Fig. 2). This 

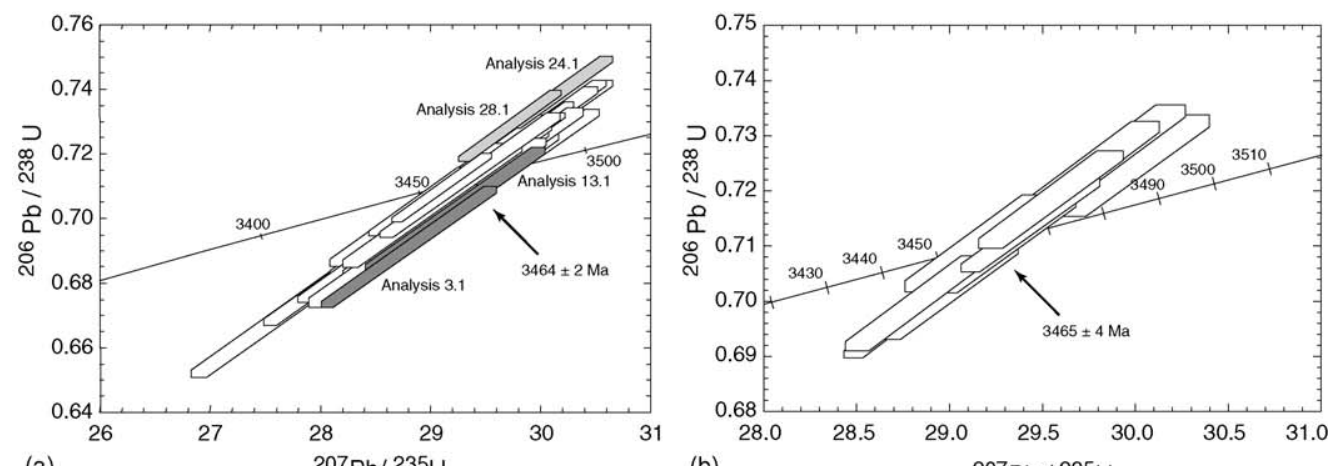

(a)

(b)
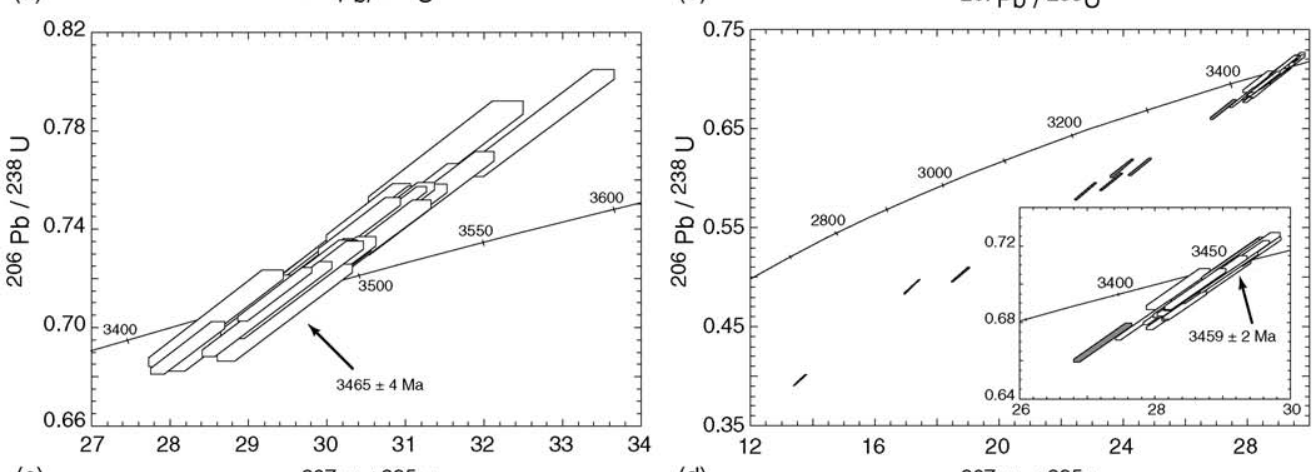

(c)

$207 \mathrm{~Pb} / 235 \mathrm{U}$

(d)
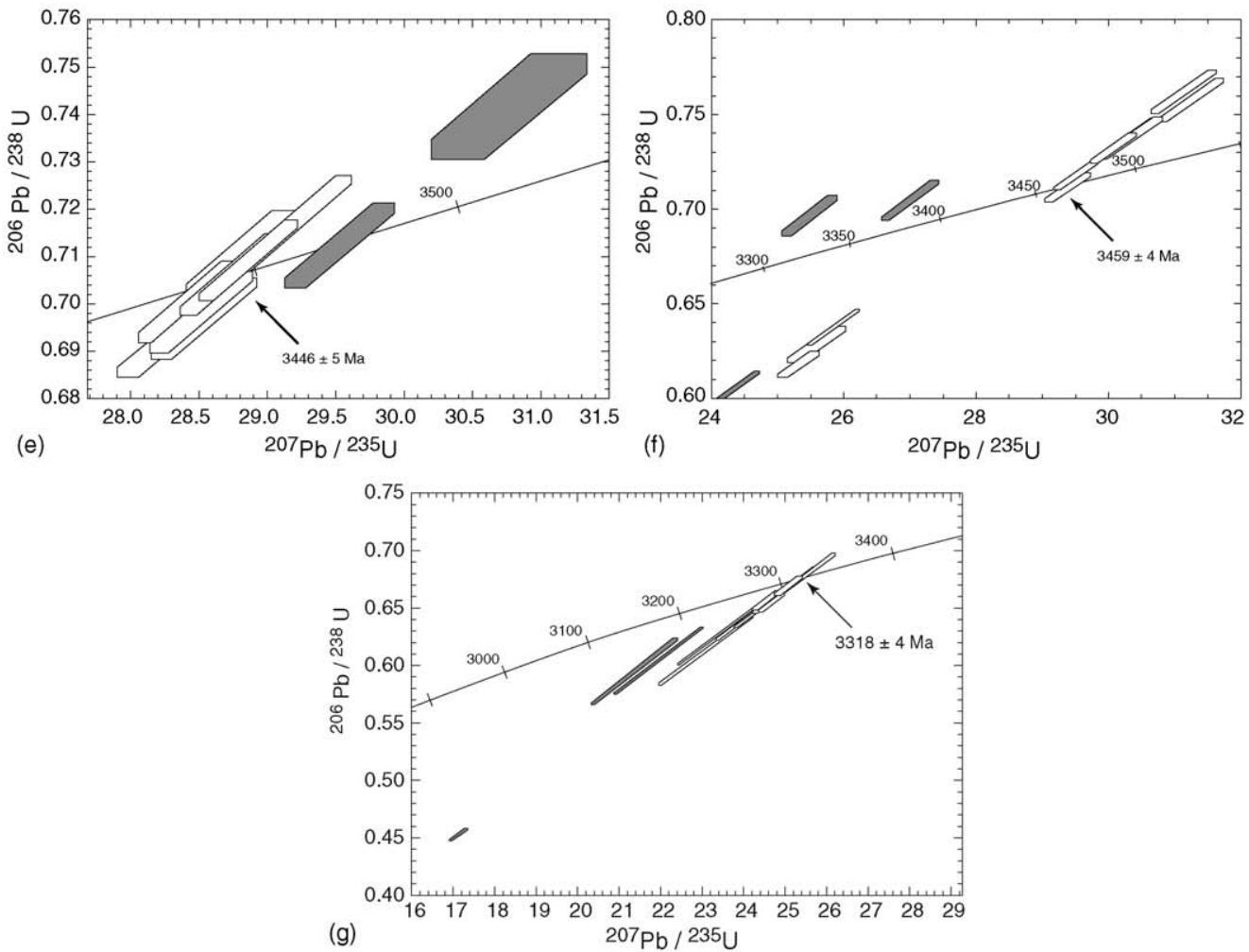

Fig. 5. (a-g) Concordia diagrams of U-Pb SHRIMP dating results obtained at Curtin University of Technology in Perth (Australia), for samples A-G respectively. For additional data see Appendix A. Locations of dated samples in Figs. 1 and 2. Data in unfilled error boxes were used to calculate the mean age. Data point error boxes are $1 \sigma$. 
Table 1

Additional details on the lithology of units F1-F4 of the Duffer Formation

\begin{tabular}{|c|c|c|c|c|c|}
\hline & \multirow{2}{*}{ West of Talga River } & \multicolumn{4}{|c|}{ East of Talga River } \\
\hline & & \multicolumn{2}{|c|}{ Directly East of Talga River } & Column B: West of BSF & Column A: East of BSF \\
\hline $\mathrm{F} 4$ & $\begin{array}{l}\text { Mainly plagioclase porphyry } \\
\text { (without quartz phenocrysts) and } \\
\text { agglomerate. }\end{array}$ & \multicolumn{2}{|c|}{$\begin{array}{l}\text { Scattered exposure of quartz- } \\
\text { bearing plagioclase porphyry. } \\
\text { Internal beddding } \sim \mathrm{E}-\mathrm{W} \text {, but rarely } \\
\text { distinguishable (Fig. } 6 \text { ). } \\
\text { Between outcrops occasional } \\
\text { exposure of } \sim \mathrm{N}-\mathrm{S} \text { oriented dolerite } \\
\text { dykes, white, altered dolomitic } \\
\text { material and veins or 'crust'-like } \\
\text { deposits of dolomite. }\end{array}$} & \multicolumn{2}{|c|}{$\begin{array}{l}\text { Upper half: massive, vesicular and occasionally pillowed basalts interbedded } \\
\text { with plagioclase porphyries. } \\
\text { Mainly massive, dacitic to andesitic plagioclase porphyry. Generally lacks } \\
\text { stratification. Abundant plagioclase phenocrysts }(15-40 \%) \text {, up to } 2-5 \mathrm{~mm} \text { in } \\
\text { size and set in a very fine-grained, grey-green groundmass that commonly also } \\
\text { contains small pyroxene phenocrysts ( } \leq 1 \mathrm{~mm}) \text {. In places, minor quartz (mostly } \\
\text { in the lower part of the unit). Agglomerate occurs locally abundantly } \\
\text { throughout the lower two-thirds. Components include coarse plagioclase } \\
\text { porphyry, fine-grained intermediate rock resembling the groundmass and } \\
\text { flattened vesicular felsic rocks ( } \sim 2-5 \mathrm{~cm}) \text {. Rarely, up to tens of cm-thick, fine } \\
\text { sand-sized, laminated tuff layers are intercalated. }\end{array}$} \\
\hline F3 & $\begin{array}{l}\text { F3? Poorly exposed. Small outcrops } \\
\text { of greenish-grey, and black, iron } \\
\text { rich, silt-sized, finely laminated } \\
\text { chert. Locally folded BIF. }\end{array}$ & Folded BIF layer & \multicolumn{3}{|c|}{$\begin{array}{l}\text { Folded basal BIF unit, locally small outcrops of plagioclase porphyritic rocks, sandstone or } \\
\text { basalt (the latter westward, } \sim \text { loc. I in Fig. 2). Overlain by } \sim 200 \mathrm{~m} \text { of felsic rocks, including } \\
\text { agglomerate (cm to } 30 \mathrm{~cm} \text {-sized plagioclase porphyry and vesicular felsic clasts in a } \\
\text { greenish groundmass) and plagioclase porphyry ( } 2-3 \mathrm{~mm} \text { phenocrysts in a light green, } \\
\text { macroscopically glassy groundmass). A second BIF interval is characterised by debris and } \\
\text { small outcrops of dark chert and BIF. }\end{array}$} \\
\hline F2 & Absent & Absent & \multicolumn{3}{|c|}{$\begin{array}{l}\text { Massive, silicified dacite with abundant plagioclase phenocrysts }(\sim 4 \mathrm{~mm}) \text { and smaller } \\
(\leq 1 \mathrm{~mm}) \text {, less abundant quartz phenocrysts. Grey-black, macroscopically glassy groundmass. } \\
\text { Locally columnar jointed. }\end{array}$} \\
\hline \multirow[t]{2}{*}{$\mathrm{F} 1$} & \multirow[t]{2}{*}{ Absent } & \multirow[t]{2}{*}{ Absent } & \multicolumn{2}{|c|}{$\begin{array}{l}\text { Strongly foliated, veryfine-grained, bright } \\
\text { green rocks. In most places altered to } \\
\text { carbonate, and occasionally contains quartz } \\
\text { lenses. Scattered outcrops of quartz-plagioclase } \\
\text { porphyry and banded iron formation in poorly } \\
\text { exposed interval. } \\
\text { Poorly exposed, fine-grained mafic rocks } \\
\text { and dark chert (mostly debris). }\end{array}$} & $\begin{array}{l}\text { Single outcrop of fine-grained mafic } \\
\text { to ultramafic rock, containing } 10 \\
\mathrm{~cm} \text {-sized enclaves with a larger } \\
\text { grainsize ( } \sim 750 \mathrm{~m} \text { east of column A, } \\
\text { Fig. 2). Remainder of interval } \\
\text { unexposed (covered by recent Eight } \\
\text { Mile Creek deposits). }\end{array}$ \\
\hline & & & \multicolumn{3}{|c|}{$\begin{array}{l}\text { Plagioclase porphyry with quartz phenocrysts }(\sim 0.5 \mathrm{~cm}) \text { and twinned plagioclase } \\
\text { phenocrysts }(\sim 0.3 \mathrm{~cm}) \text { surrounded by an extremely fine-grained, dark, groundmass with a } \\
\text { glassy field appearance. Mostly massive, lacking stratification. Locally columnar jointed. }\end{array}$} \\
\hline
\end{tabular}

For columns A and B see Figs. 2 and 4.

is comparable to dates of the Duffer Formation in the western extension of the greenstone belt, which define a similar range between 3470 and $3461 \mathrm{Ma}$ (loc. 1-3 and 7; Fig. 9 and Table 2 and references therein).

Based on these new dates, the lowermost felsic unit east of the Coppin Gap Suite, with an age of $3471 \pm 5 \mathrm{Ma}$ (loc. 9, Fig. 1), can be correlated with the Duffer Formation in the central Coppin Gap Greenstone Belt (Fig. 9), confirming the map correlation of Williams (1999).

A detailed stratigraphic and sedimentological study of felsic to intermediate rock successions in the adjacent Marble Bar Greenstone Belt and the Coongan and Kelly Greenstone Belts was carried out by DiMarco and Lowe (1989b). The up to $2.8 \mathrm{~km}$ thick successions of volcaniclastic breccia, conglomerate and turbiditic tuff that they reported from these belts are absent from the study area. Instead, the central part of the Coppin Gap Greenstone Belt contains a greater amount of lavas and agglomerates. DiMarco and Lowe (1989b) assigned the major part of the felsic to intermediate succession in the Kelly Greenstone Belt to the Duffer Formation. Barley et al. (1998), however, showed that the age of the felsic rocks in the lower part of the Kelly Greenstone Belt is $3417 \pm 9 \mathrm{Ma}$, which is ca. 50 Ma younger than the Duffer Formation in the Coppin Gap and Marble Bar Greenstone Belts. Therefore, it is impossible to correlate the felsic to intermediate units between different greenstone belts as a single episode of volcanism under a single formation name (cf. Barley et al., 1998).

\subsubsection{Towers Formation(?)}

The poorly exposed basalts and the locally silicified, grey to reddish siltstones to fine-grained sandstones that were observed at several places at the top of the Duffer Formation, may be stratigraphically equivalent to units of the Towers Formation, which overlies the Duffer Formation in the adjacent Marble Bar Greenstone Belt (Van Kranendonk et al., 2002). The poor quality of the expo- 
Table 2

Origin and age of dating samples from the Coppin Gap and Marble Bar Greenstone Belts

\begin{tabular}{|c|c|c|c|c|}
\hline Loc. & Sample number & Age (Ma) & AMG ref./coordinates & Reference \\
\hline A & A (VM00-255) & $3464 \pm 2$ & $50 \mathrm{KQB} 981799$ & This study ${ }^{1}$ \\
\hline $\mathrm{B}$ & B (W95-28) & $3465 \pm 4$ & $50 \mathrm{KRB} 105813$ & This study $^{1}$ \\
\hline $\mathrm{C}$ & C (W98-5) & $3465 \pm 4$ & $51 \mathrm{KSS} 913836$ & This study ${ }^{1}$ \\
\hline $\mathrm{D}$ & D (VM00-124) & $3459 \pm 2$ & $51 \mathrm{KSS} 935843$ & This study ${ }^{1}$ \\
\hline $\mathrm{E}$ & E(JW95-001) & $3446 \pm 5$ & 51 KSS 950863 & This study $^{1}$ \\
\hline $\mathrm{F}$ & $\mathrm{F}$ (W94.22.3) & $<3459 \pm 4$ & 51 KTS 025872 & This study ${ }^{1}$ \\
\hline $\mathrm{G}$ & G (W95-36) & $<3318 \pm 4$ & $50 \mathrm{KRB} 022835$ & This study ${ }^{1}$ \\
\hline 1 & & 3465 & & Thorpe (1999) written comm. (in Van Kranendonk et al. (2001b)) \\
\hline 2 & UWA-98076 & $3466 \pm 4$ & $21^{\circ} 06^{\prime} 27^{\prime \prime} \mathrm{S}, 119^{\circ} 45^{\prime} 28^{\prime \prime} \mathrm{E}$ & McNaughton et al. $(1993)^{1}$ \\
\hline 3 & GSWA 148509 & $3468 \pm 2$ & $21^{\circ} 05^{\prime} 56^{\prime \prime} \mathrm{S}, 119^{\circ} 46^{\prime} 30^{\prime \prime} \mathrm{E}$ & Nelson $(2000)^{1}$ \\
\hline 4 & GSWA 148498 & $3477 \pm 2$ & $21^{\circ} 03^{\prime} 11^{\prime \prime} \mathrm{S}, 119^{\circ} 47^{\prime} 09^{\prime \prime} \mathrm{E}$ & Nelson $(2000)^{1}$ \\
\hline 5 & 96JW022 & $3490 \pm 15$ & 7673414,795935 & Beintema $(2003)^{2}$ \\
\hline 6 & GSWA 148500 & $3469 \pm 3$ & $20^{\circ} 59^{\prime} 35^{\prime \prime} \mathrm{S}, 119^{\circ} 49^{\prime} 19^{\prime \prime} \mathrm{E}$ & Nelson $(1999)^{1}$ \\
\hline 7 & ANU89-332 & $3463 \pm 2$ & $21^{\circ} 57^{\prime} 12^{\prime \prime} \mathrm{S}, 119^{\circ} 50^{\prime} 59^{\prime \prime} \mathrm{E}$ & McNaughton et al. (1993) ${ }^{1}$ \\
\hline 8 & GSWA 100511 & $3458 \pm 2$ & AMG 997866 & Thorpe (1991) written comm. (in Williams $(1999))^{3}$ \\
\hline 9 & GSWA 100512 & $3471 \pm 5$ & $20^{\circ} 56^{\prime} 20^{\prime \prime} \mathrm{S}, 120^{\circ} 10^{\prime} 09^{\prime \prime} \mathrm{E}$ & Thorpe et al. $(1992 b)^{3}$ \\
\hline 10 & GSWA 94770 & $3454 \pm 1$ & $20^{\circ} 55^{\prime} 16^{\prime \prime} \mathrm{S}, 120^{\circ} 11^{\prime} 01^{\prime \prime} \mathrm{E}$ & Thorpe et al. $(1992 b)^{3}$ \\
\hline $10^{*}$ & GSWA 94770 & $3470 \pm 2$ & $20^{\circ} 55^{\prime} 16^{\prime \prime} \mathrm{S}, 120^{\circ} 11^{\prime} 01^{\prime \prime} \mathrm{E}$ & Thorpe et al. $(1992 b)^{3}$ \\
\hline
\end{tabular}

Sample locations are indicated in Figs. 1 and 2. Dating method: ${ }^{1}$ SHRIMP zircon U-Pb, ${ }^{2} \mathrm{Ar}-\mathrm{Ar},{ }^{3} \mathrm{Conventional} \mathrm{zircon} \mathrm{U-Pb.} \mathrm{SHRIMP} \mathrm{dating} \mathrm{for}$ this study was done at Curtin University of Technology in Perth, Australia, details in Figs. 5a-g and Appendix A. 10*: Xenocrysts in sample 10.

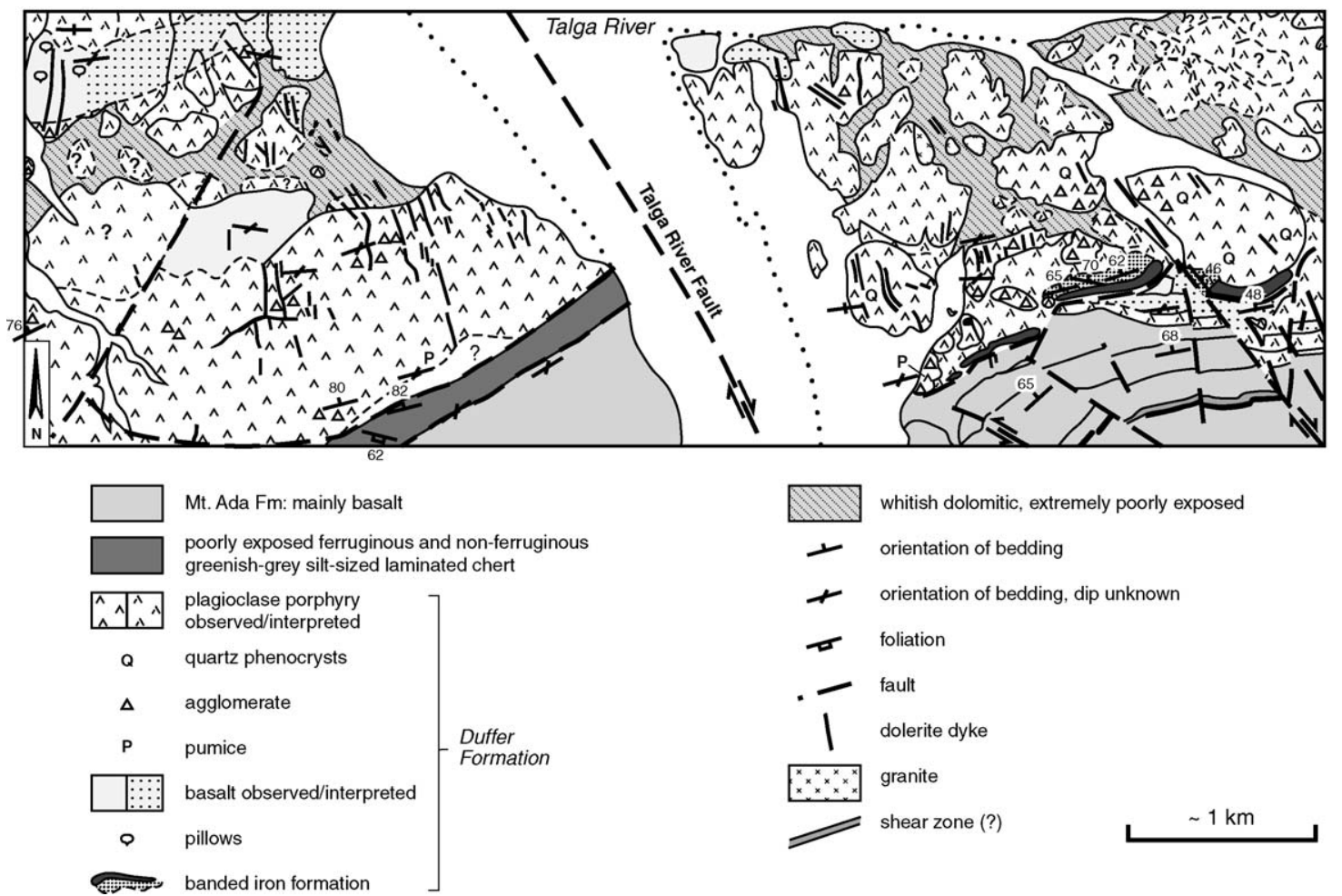

Fig. 6. Detailed map of the lower part of the Duffer Formation in the western part of the study area, where it has a fragmented appearance. For location see Fig. 2. 


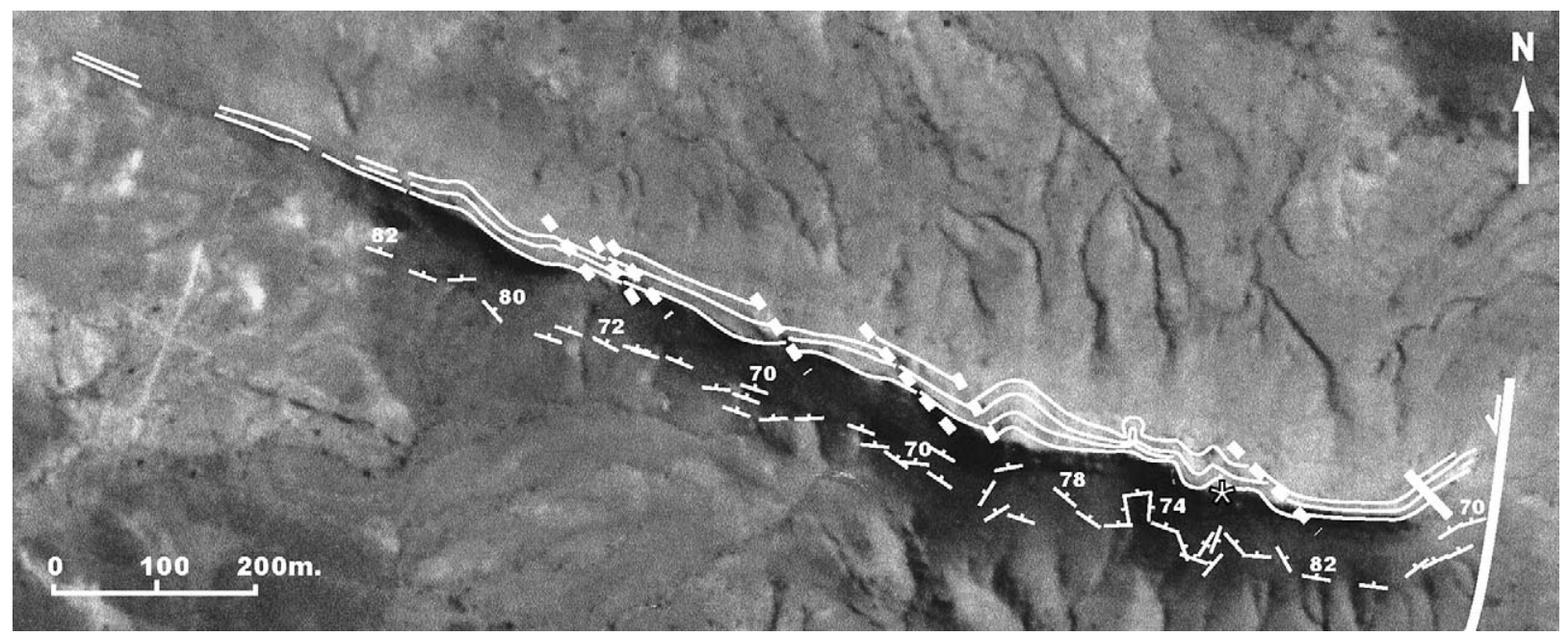

Fig. 7. Western outcrop of the Razorback Chert, with folding (east) and antithetic normal faults, partly reactivated as thrust faults. Orientations of bedding are plotted below the outcrop. Eastern end of outcrop bends in northern direction, indicating west-block-down movement on normal fault. Approximate location of Fig. 10 indicated with an asterisk.
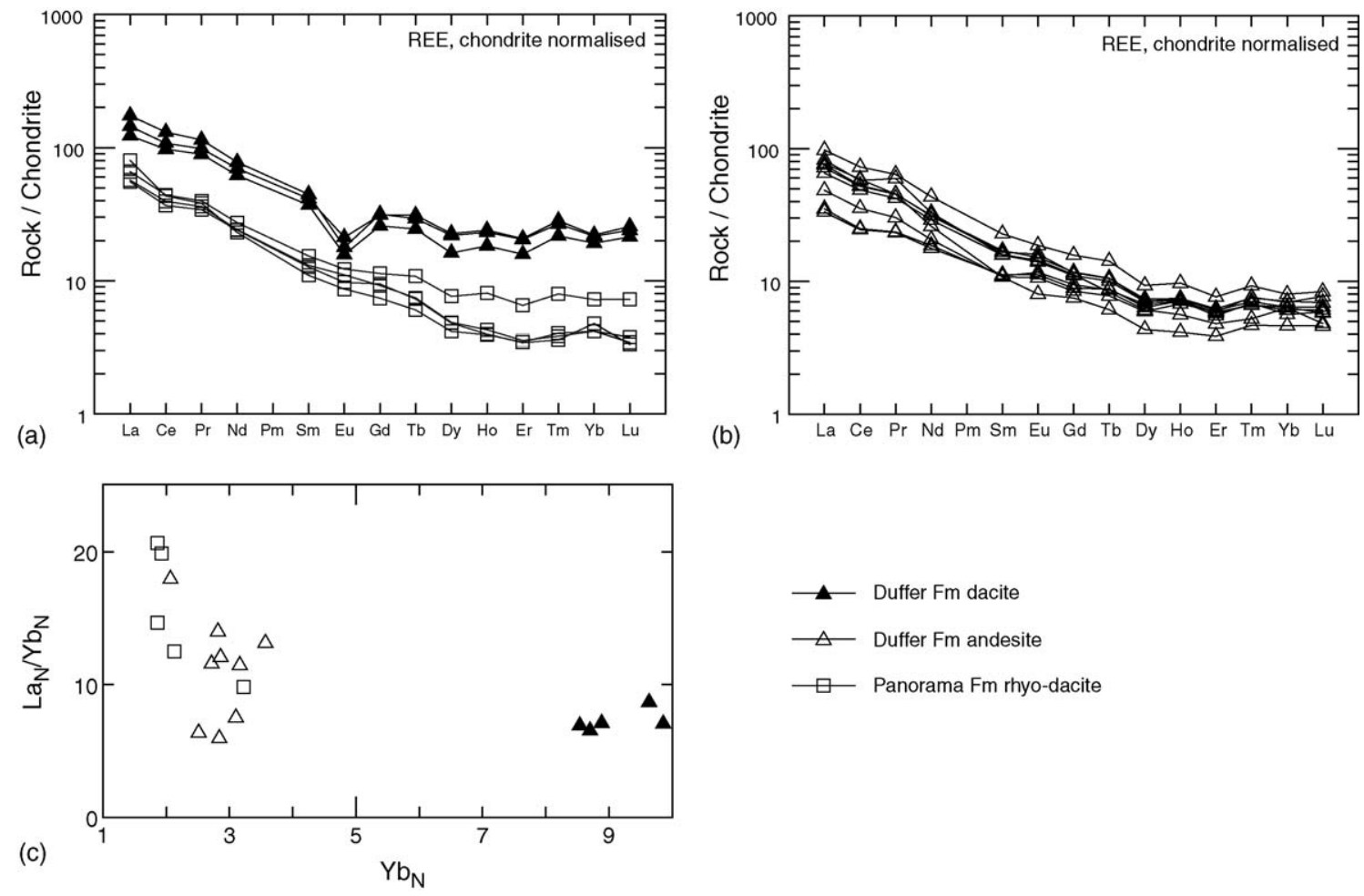

Fig. 8. REE patterns for Duffer Formation dacites and Panorama Formation rhyodacite (a) and Duffer Formation andesite (b) samples. Concentrations are chondrite normalised (Nakamura, 1974). (c) Chondrite normalised La/Yb ratio versus normalised Yb content. Note the difference between dacitic Duffer Formation and rhyodacitic Panorama Formation rocks. 
sure in the study area precludes detailed comparison with the rock succession in the Marble Bar Belt as well as conclusions about the depositional setting of these rocks.

\subsubsection{Apex Formation}

The plagioclase porphyry (sample D, Fig. 9) between the 'Towers Formation' and the serpentinised peridotite is slightly younger than the underlying felsic rocks of the Duffer Formation (samples A-C, Fig. 9). Williams (1999) considered this unit to be part of the Apex Formation, a lithostratigraphic unit characterised by basalt (e.g. Hickman, 1983). The andesitic nature of sample D, and its geochemical similarity to the andesites lower in the stratigraphy, characterise this plagioclase porphyry as an intercalation of Duffer Formation in the Apex Basalt. Its age of $3459 \pm 2 \mathrm{Ma}$ is similar to that of a felsic unit located to the northeast (geochronology loc. 8 in Fig. 1), which has a quartz-porphyritic character (Thorpe et al., 1992b), comparable to the Panorama Formation. Combined, the observations indicate that in the Coppin Gap Greenstone Belt, the Apex Formation is transitional between the Duffer and Panorama Formations. The age of the samples falls within the range of the Panorama Formation elsewhere in the East Pilbara (ca. 3459-3428; Thorpe et al., 1992b; Nelson, 2001; Van Kranendonk et al., 2002).

\subsubsection{Panorama Formation}

The interbedding of agglomerates, flow-banded porphyries and, near the stratigraphic top of the unit, vol- caniclastic layers, indicates that at least part of the massive Panorama Formation rhyolites and rhyodacites were extrusive. The overlying, now silicified, sediments were deposited in shallow water (see De Vries et al., 2006). The succession in the Coppin Gap Greenstone Belt seems comparable to the Panorama Formation at its type section (Panorama Ridge) in the North Pole Dome, where Hickman (1983) described the lower part of the formation as being composed of dacitic lava, tuff and agglomerate, and the upper part of the section as consisting predominantly of quartzite and chert. DiMarco and Lowe (1989a) regard the Panorama Formation in the North Pole Dome as a volcanically controlled fan-delta complex. They described it as mainly consisting of shallow-water, volcaniclastic deltaic deposits that locally interfinger with volcaniclastic breccia and felsic lava.

\section{Structural geology of the Coppin Gap Greenstone Belt}

\subsection{New structural data}

Since the focus of this study is on the earliest deformation phases, the descriptions in this section will also be confined to early (i.e. pre- $3.3 \mathrm{Ga}$ ) structures. The two major early structural features in the study area are $\sim$ NNE-SSW oriented normal faults, in places organised in arrays, and bedding-parallel to low-angle deformation zones. The early character of these structures can

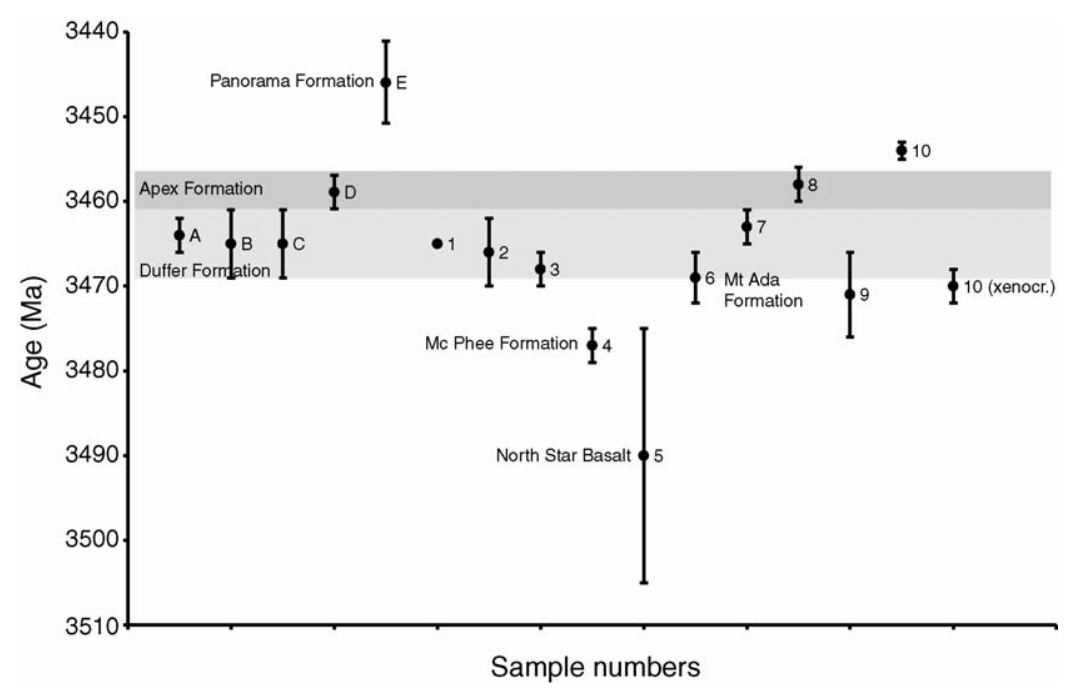

Fig. 9. Plot of dates including error bars from Warrawoona Group in the Marble Bar and Coppin Gap Greenstone Belts. Letters refer to new dates presented in this study, numbers refer to previously published dates of the Warrawoona Group in this area. Shaded intervals are based on dates presented in this paper. Sample F is much younger and is therefore not included in this figure. For locations see Fig. 1, for details on geochronology and references, see Table 2. 
be deduced from the fact that they are intra-formational and/or truncated by other early-mid-Archaean structures or intrusions.

\subsubsection{Normal faults}

The Coppin Gap Greenstone Belt shows several arrays of west-block down normal faults that occur at different stratigraphic levels.

\subsubsection{Kittys Gap volcano-sedimentary complex ( $K G$ -} vsc). The normal-faulted KG-vsc (see Stratigraphy and Fig. 3) is located in the northeastern part of the study area, between the Bamboo Creek Shear Zone (BCSZ) and a complex basal detachment zone into which the listric normal faults merge at about $1 \mathrm{~km}$ below the top of the unit. Evidence for the syndepositional character of the faults is provided by the intraformational character of the fault array, the rotation of the fault blocks, the decreasing offset upwards along the fault planes and the stratigraphic thickening in the hanging walls towards the faults. The most obvious example of the eastward stratigraphic expansion is the siltstone-sandstone-shale wedge in the eastern part of the map area (Fig. 3). In this area, the sediment wedges onlap westward onto the previously deposited sediments. In the western part of the area, wedges of silicified sediments have been slightly thrust over each other in westward direction. Deposits in the hanging walls at the western end of the fault array show a progressive NW-SE deflection of the strike of bedding. Eastward, the faults extend to higher stratigraphic levels. At the base of the KG-vsc, $100 \mathrm{~m}$-scale blocks of felsic volcanic rock and underlying pillow basalts have been rotated and displaced (cf. Nijman et al., 1998b).
4.1.1.2. Upper part of the Duffer Formation. In the central part of the study area, just south of Talga Peak, the top of the Duffer Formation and the overlying poorly exposed basalts and silty sedimentary rocks are cut by an array of west-block-down normal faults. As with the KG-vsc, the strike of the top of the Duffer Formation, the basalts and silty sedimentary rocks and the gabbropyroxenite intrusion in this succession have been rotated clockwise with respect to the general strike of the Duffer Formation in this area (Fig. 2). Offsets on the gabbropyroxenite intrusion are up to $325 \mathrm{~m}$, while the offset of the serpentinised peridotite sill above the Towers Formation is approximately $160 \mathrm{~m}$.

4.1.1.3. The Razorback Chert. Deformation of the Razorback Chert east of the BSF includes normal faulting with west-block-down offsets. Smaller antithetic normal faults and synthetic thrust faults occur within the fault blocks (e.g. Fig. 7). In the eastern part of the outcrop intra-formational buckle-folds occur in the chert on a scale of tens of metres, with fold axes plunging $\sim 70-80^{\circ} \mathrm{N}$. Subsidiary folds show a greater variation in axial plunge (Fig. 10).

4.1.1.4. Normal faults at greenstone-belt scale. The BSF is the most prominent example of a normal fault that occurs at the scale of an entire greenstone belt. The oldest stratigraphic unit visibly involved in the displacement is the chert unit below the Duffer Formation. Together with the overlying deformation zone, it is strongly drag-folded against the fault (Fig. 2). Along the BSF, lithological boundaries, early intrusions and early bedding-parallel tectonic structures seem to show a systematic decrease in offset towards higher levels of the stratigraphic col-

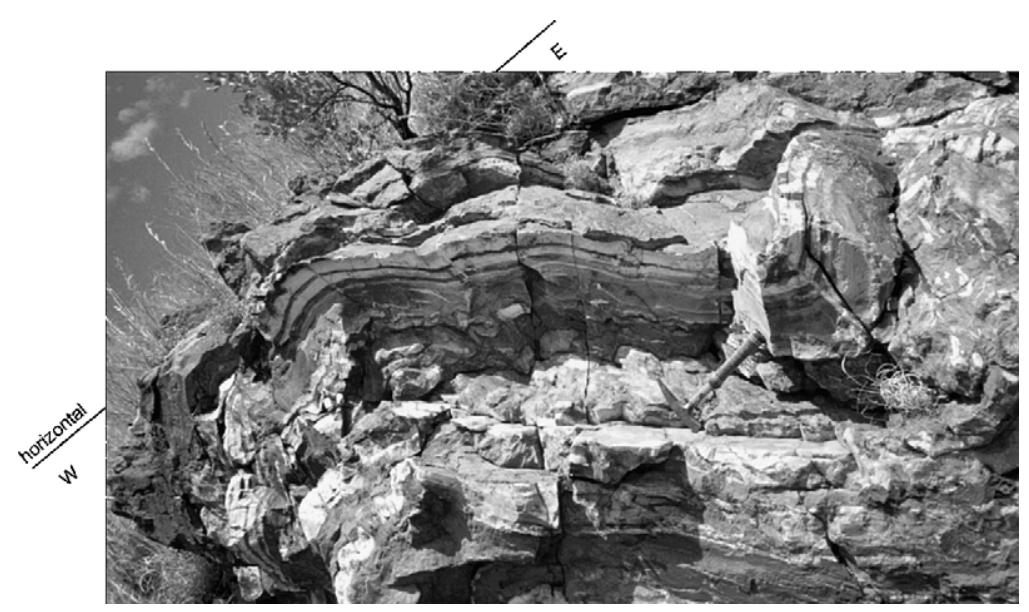

Fig. 10. Intra-formational, metre-scale folding in the western chert ridge of the Razorback Chert. Approximate location indicated in Fig. 7. 
umn. This suggests that the BSF may have been active as a major normal fault during deposition of a large part of the Warrawoona Group.

\subsubsection{Deformation zones}

The study area contains a number of bedding-parallel to low-angle deformation zones. These chemically and mineralogically altered zones are characterised either by foliation or by folding as the first deformation. The style of deformation mainly depends on the lithology. Foliation is often observed in zones with intense chemical alteration of mafic and ultramafic rocks to dolomite, chlorite, talc and serpentinite. Zones that are similar in appearance on aerial photographs but have not been further identified, have been marked as alteration zones in Fig. 2. The deformation zones are truncated by the $3314 \pm 13$ Ma Coppin Gap Suite of the Mt Edgar Granitoid Complex (date from Williams and Collins, 1990), and thus were formed early in the history of the Coppin Gap Greenstone Belt.

\subsubsection{Foliation zones. The Razorback Shear Zone:} east of the BSF, basalts between the Razorback Chert and the quartz-plagioclase porphyry at the base of the Duffer Formation have been deformed. The deformation is concentrated in a zone along the lower contact of the basalt with the Razorback Chert, and an upper zone within the basalt, $\sim 100-200 \mathrm{~m}$ below the Duffer Formation. The upper zone exhibits a well-developed, approximately strike-parallel foliation, which anastomoses around strongly altered lenses of mafic rock. In places, the first foliation is folded on cm-scale and metrescale as a result of a subsequent phase of deformation (Fig. 11). Numerous quartz veins, ranging in width from 1 to $20 \mathrm{~cm}$, intersect the shear zone. In places, the veins are boudinaged or folded. To the west, the shear zone is cut by the BSF. West of the fault, shear zones at several levels in the rock succession may be correlated to this upper shear zone.

The rocks in the top of F1 at the location of column $B$ are intensely foliated. Laterally and upwards, the zone is extremely poorly exposed, and covered by dolomitic crusts and debris. East of the BSF this interval is obscured by Eight Mile Creek.

The Serpentinite Shear Zone (SSZ) is a well-exposed foliation zone that is closely associated with the serpentinised peridotite that intruded basalts, siltstones and plagioclase porphyry units overlying the Duffer Formation. Both the serpentinised peridotite and the shear zones obliquely truncate rock succession, thereby descending in the stratigraphic column from east to west. The shear is concentrated along the contacts of the serpentinised peridotite with the adjacent rock units, but the peridotite also shows some internal shearing.

Shear zones also occur at higher stratigraphic levels, above and below the Kittys Gap volcano-sedimentary succession (for description see Nijman et al., 1998b).

4.1.2.2. Fold zones. A complex zone of deformation occurs in the lower part of the Duffer Formation, at the level of the BIF intervals (unit F3). It either separates parts of the rock succession with slightly deviating

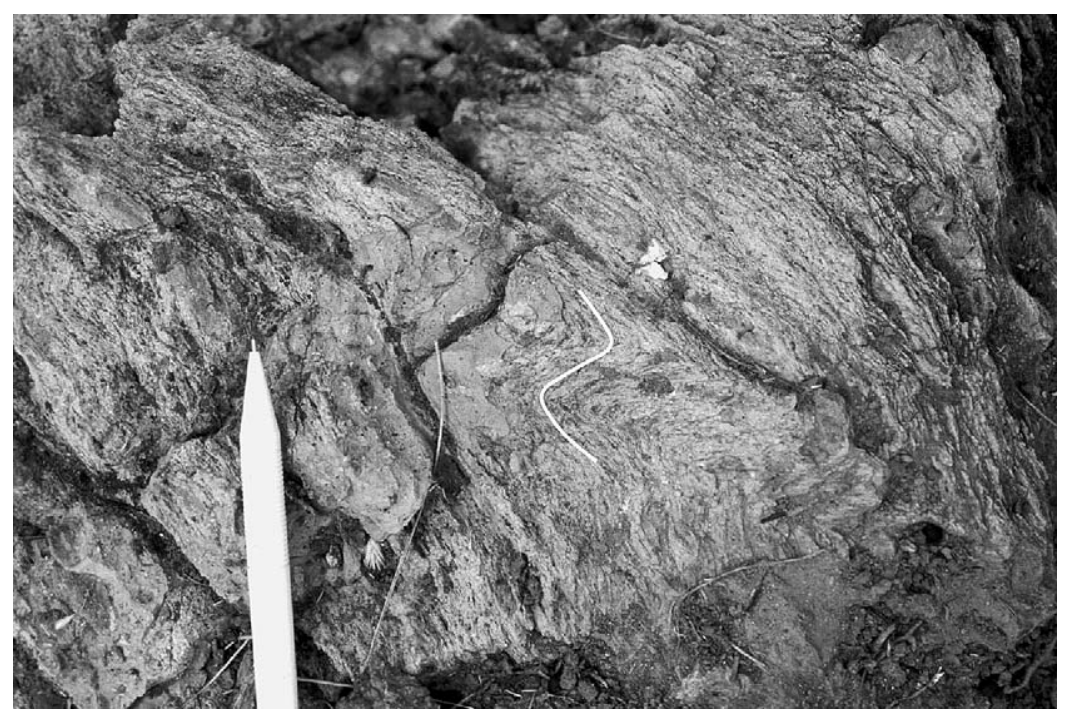

Fig. 11. Centimetre-scale folding of the foliation in the Razorback Shear Zone $\sim 100-200 \mathrm{~m}$ below the Duffer Formation. 
strikes (Fig. 2, east of the BSF) or it marks a westwardincreasing hiatus involving the lower Duffer Formation and the top of the underlying Mt Ada Basalt succession (respectively east and west of the BSF in Fig. 2).

In the entire study area, decimetre to metre-scale S-folds are observed in the lower BIF unit. These are particularly well exposed at location SV01-70 (Fig. 12) in column B (Figs. 2 and 4). Fold axes are dominantly subvertical but variable and in places even become almost horizontal (Fig. 12a). At location SV01-70 (column B), the lower BIF unit is buckled and recumbently folded (Fig. 12b and c).

Three kilometres further to the west (location I in Fig. 2), BIF (F3) is in anomalous contact with porphyry F1. Still further to the west (loc. II, Fig. 2), the entire lower part of the Duffer Formation (F1 and F2) is absent and BIF is in direct contact with the underlying Mt Ada Basalt. At this location, the folded BIF curves around large fragments of Duffer Formation felsic rocks, comparable to what was observed on a minor scale at location SV01-70 (Fig. 12c) and to features described along the base of the KG-vsc (see above). West of the Talga River Fault, the anomalous juxtaposition of Duffer Formation unit F4 and the Mt Ada Basalt persists, and units F1 and F2 remain absent (Fig. 2).

In the opposite direction, east of loc. SV01-70, the deformation zone is offset in west-block down stepping listric faults between column B and the BSF. In the vicinity of the contact with the Coppin Gap Suite of the Mt Edgar Granitoid Complex, the strike of the BIF unit deflects from the general ESE orientation into a SE orientation. The basal Duffer Formation succession in this area has probably been complicated by thrust duplication. This complex is unconformably covered by felsic rocks of $\mathrm{F} 4$. The latter observations are based on a radar image of the area (Coppin Gap 062-1(B), NASA/JPL AIRSAR, ac. 19 September 1993, process ID TS0037) and on limited field observations in a generally poorly exposed area.

\subsection{Interpretation of structures: extension in the Coppin Gap Greenstone Belt}

\subsubsection{Extension in the $K G$-volcano-sedimentary complex (Panorama Formation)}

In the KG-vsc, thickness differences across the faults, the progressive tilting of the succession and the presence of rollover anticlines indicate the syndepositional character of the normal faults that cut the complex (Fig. 3). The geometric relationships indicate a back (i.e. eastward)-stepping of the normal faults during deposition. During this process of back-stepping, compressive structures developed in the toe (west) of the fault-array while extension dominated at the rear (east). In the west, the successions became progressively rotated and normal faults were folded. Downwards, the normal faults end in a series of shear zones stratigraphically $\sim 1 \mathrm{~km}$ below the top of the fault array (Fig. 3). Tensile faults occurring at the rear of a fault array and broadly contemporaneous compressive features along the sole of the normal faults and in front of the fault array are characteristic of gravitational collapse (e.g. Mandl and Crans, 1981). Nijman et al. (1998b) observed inversion from tensile (in present map-view sinistral) to compressive (in present map-view dextral) displacement on this detachment zone. The rotation and displacement of large blocks at the base of the fault array (Fig. 3), and the broad, brittle deformation zone indicate that sliding at the detachment surface took place under relatively low overburden pressure, i.e. close to the palaeo-surface. Dating of felsic rocks in the lower part of the KG-vsc (sample E, this study) constrains the time of deposition, and hence of faulting in the KG-vsc to $\sim 3446 \mathrm{Ma}$ (i.e. Panorama Formation age).

\subsubsection{Extension and gravitational collapse in the Duffer Formation}

Lower in the Warrawoona Group, there is also evidence for extensional faulting. The fault array in the top of the Duffer Formation has a similar orientation to the faults in the KG-vsc. Syndepositional activity along these faults is suggested by the strike rotation of the rocks in that area, and the differential offset of the gabbro intrusion and the (stratigraphically) slightly higher, serpentinised peridotite intrusion.

The intraformational folding and faulting along the deformation zone in unit F3 of the Duffer Formation is restricted to the lower BIF unit. It accounts for local excisions and duplications of stratigraphy, and differences in thickness and strike in and along this unit. The dominance of S-folding throughout the deformation zone points to a sinistral sense of movement (pre-rotation of bedding into a vertical position: upper block to the west). The incorporation of felsic and mafic blocks in the folded outcrops, and the locally brittle character of the deformation, indicate that the movement took place under a low overburden pressure. Towards the west (i.e. in the direction of movement), the deformation zone gradually excises the underlying part of the Duffer Formation, while the outcrop pattern of Duffer Formation unit F4 shows decreasing 'consistency'. Combined, these observations suggest surficial (i.e. uppermost crustal) gravitational deformation (or collapse), which affected a large part of the Duffer Formation. The fracturing of the upper block (unit F4) allowed the formation of path- 


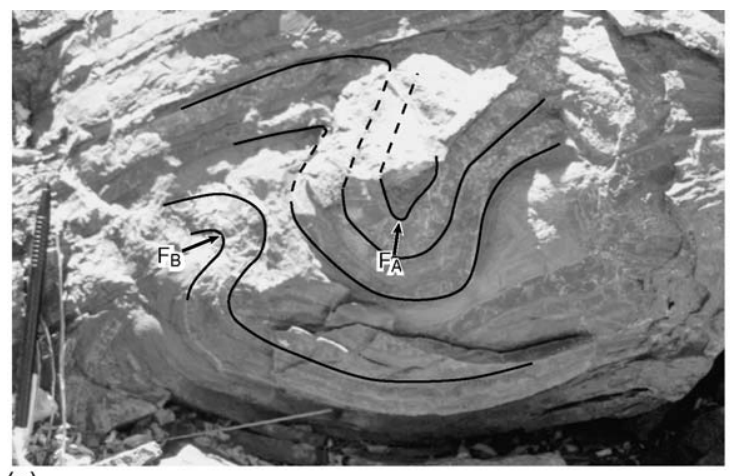

(a)

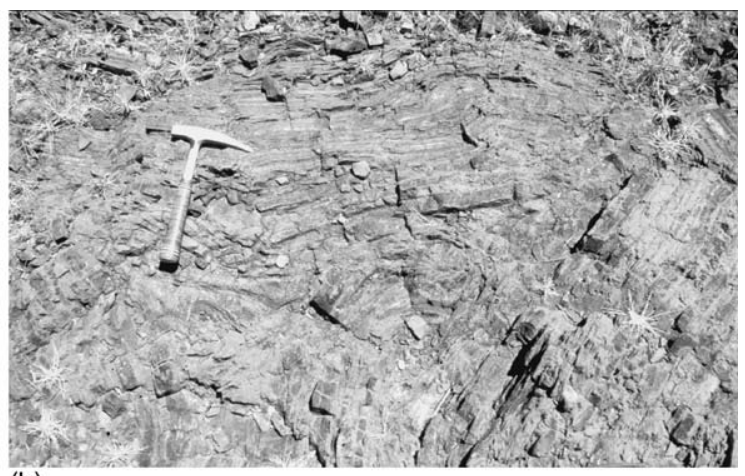

(b)

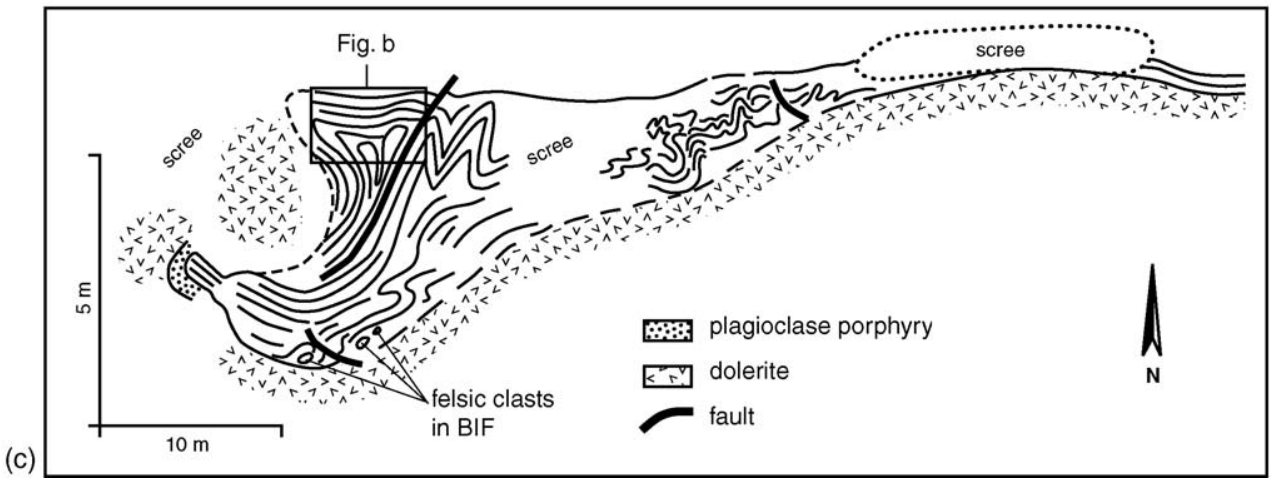

Fig. 12. Examples of intra-formational folding of the lower BIF unit in the Duffer Formation. (a) Folding in BIF unit north of loc. I (Fig. 2); fold axis $F_{A}: 36 / 044 ; F_{B}: 44 / 036$. (b) Folding with near-vertical fold axes at location ST01-70 (just west of composite column B). (c) Sketch of intensely folded lower BIF unit at location ST01-70. Location of (b) indicated with a rectangle.

ways for fluids and magma, which resulted in veins, dykes and alteration of the host rocks. This interpretation fits the observations better than the interpretation of a 'megabreccia' in this area (Nijman et al., 1998b), particularly since there are no indications of block rotations or major disruptions of the stratigraphic succession.

The intraformational extensional faulting and thrusting that has complicated the lower Duffer Formation in the vicinity of the contact with the Coppin Gap suite of the Mt Edgar Granitoid Complex, also fits with extensional detachment along the fold zone.

A similar style of detachment deformation, including recumbent northwest-facing folds, was described by Collins (1989) from the McPhee Reward area in the western extension of the greenstone belt (where it curves into the $\mathrm{N}-\mathrm{S}$ oriented Marble Bar Greenstone Belt). Although these folds were interpreted as collapse structures resulting from doming of the Mt Edgar Granitoid Complex (Collins, 1989), they could equally well be gravitational collapse structures along detachment surfaces such as interpreted from the central Coppin Gap Greenstone Belt (see also Nijman and De Vries, 2004).

\subsubsection{Extension of pre-Duffer Formation rocks}

Stratigraphically below the Duffer Formation, there is also evidence for early extensional deformation. In the Razorback Chert, the lateral thickness difference away from one of the controlling normal faults (Fig. 7) suggests that this fault was active during its deposition. Later reactivation may subsequently have caused a larger offset on the major faults. The observed buckle folds suggest internal, bedding-parallel slip planes in the Razorback Chert. Both the buckle folds and the folds with variably plunging fold axes are interpreted as surficial collapse folds related to synsedimentary, intra-formational slip. Small normal faults, antithetic to the controlling normal fault were (partly) reactivated as minor thrust faults during compression in the toe region of such collapse features. However, time control on the formation of the compressive structures in the Razorback Chert, and hence their synsedimentary character, is less certain than for the Kittys Gap volcano-sedimentary complex.

The position of the Razorback Chert below the base of the Duffer Formation indicates that the extension took place prior to $3465 \pm 4 \mathrm{Ma}$ (sample B; basal Duffer 
Formation quartz-plagioclase porphyry). The Razorback Chert may be correlated westward across the BSF to the only chert present below the Duffer Formation in that area, which can be followed westward along strike to correlate with the McPhee Chert in the Marble Bar Greenstone Belt (McPhee Formation, dated at $3469 \pm 3$ Ma at the McPhee Reward Mine, loc. 6, Fig. 1). The apparent thickness difference in map view (Fig. 2) between the rock successions of the lower Warrawoona Group on both sides of the BSF (i.e. above the Razorback Chert and its possible equivalent on the western side of the fault) is largely due to the much lower dip of the bedding on the west side of the fault.

\subsubsection{Role of the BSF and other major faults}

The BSF may have acted as a major west-blockdown growth fault during deposition of a major part of the Warrawoona Group. The presence of another largescale, early structure in the Coppin Gap Greenstone Belt is implied by the misfit between the rocks successions on both sides of the Coppin Gap suite of the Mt Edgar Granitoid Complex. Although the present-day distance between the sections of Warrawoona Group on both sides is only $\sim 7.5 \mathrm{~km}$, the rock successions (that can now be correlated based on the new $\mathrm{U}-\mathrm{Pb}$ dates) do not resemble each other (maps by Nijman et al. (1998b) and Williams (1999)). This suggests that a major normal fault or other structure occurred at the location of the Coppin Gap granitoid suite, prior to its intrusion at ca. $3314 \pm 13 \mathrm{Ma}$ (Williams and Collins, 1990).

\section{Extensional tectonics and stratigraphic continuity}

\subsection{Regional significance of the extensional tectonics}

The above observations are not the only indications for extensional deformation and normal faulting in the Coppin Gap Greenstone Belt and its immediate vicinity. At the easternmost extremity of the Coppin Gap Greenstone Belt, where it curves into a NW-SE direction, an array of northwest-block-down normal faults affects a basalt unit and overlying silicified sedimentary rocks (Nijman et al., 1998b; Zegers et al., 2002). The occurrence of a wedge of tuff and/or shale related to these faults indicates their synsedimentary character. Deposition of these basalts and overlying silicified sediments, and therefore also the observed normal faulting, are constrained between $3454 \mathrm{Ma}$ (date 10 in Fig. 1) and $3415 \mathrm{Ma}(\mathrm{Pb}-\mathrm{Pb}$ model age of galena from the BCSZ by Zegers et al. (2002); cf. Thorpe et al. (1992a)).
Kloppenburg (2003) reported extension in the central part of the Coppin Gap Greenstone Belt during deposition of the Apex and/or Euro Basalts, based on observations on a swarm of dolerite dykes in the Duffer Formation. Dates from our study constrain deposition of the Apex Basalt in the study area to between ca. 3459 and $<3446$ Ma (samples D and E). Deposition of the Euro Basalt is constrained to between $\sim 3446$ and $3415 \mathrm{Ma}$ (dates of the underlying Panorama Formation and the truncating BCSZ, respectively). Hence, the extension related to the intrusion of the dolerite dykes is interpreted to have taken place between 3459 and 3415 Ma.

From the McPhee Reward area, faulting during deposition of the top of the North Star Basalt (Beintema, 2003) and/or the Warrawoona Group (Van Haaften and White, 1998) was reported. Both authors found subsequent east-west extension, and east-west compression that they interpreted to have occurred at $\sim 3450$ and $\sim 3300$ Ma, respectively.

Finally, extension during deposition of the Warrawoona Group was not a local phenomenon in the Coppin Gap Greenstone Belt, but also occurred in other greenstone belts of the East Pilbara. Syndepositional extensional structures such as normal fault arrays have been reported from the Coongan Greenstone Belt (Zegers et al., 1996), the Kelly Greenstone Belt and Marble Bar area (Oliver and Cawood, 2001; Kloppenburg, 2003) and the North Pole Dome (Nijman et al., 1998a; Van Kranendonk et al., 2001b).

\subsection{Orientation of the stress field and duration of the extensional regime}

Reconstruction of the orientation of the stress field that led to the formation of the extensional structures in the Coppin Gap Greenstone Belt requires correction for folding and granitoid doming that affected the rock succession. Since the greenstone belts in the East Pilbara generally show semi-circular outcrop patterns around the granitoid batholiths, a rotation around axes parallel to the outlines of these complexes is the most obvious method for reconstruction of the syndepositional structural setting. Applying this method to the observed normal-fault arrays, associated compressional folds and other extensional structures in the study area, all of them, including the dykes in the Apex and/or Euro Basalts, point to a consistent, east-west direction of extension in the Coppin Gap Greenstone Belt. This interpretation is different from the conclusion of Kloppenburg (2003), who interpreted a regional, linear field of NE-SW extension for syn-Warrawoona Group dyke swarms in the Kelly, Marble Bar and Coppin Gap greenstone belts, based on 
the assumption that the dykes were part of a cylindrical fold. However, this method of reconstruction is neither applicable to the eastern parts of the Coppin Gap Greenstone Belt, nor to other normal-faulted areas in the East Pilbara.

The occurrence of growth faults and fault arrays with a consistent E-W orientation at different stratigraphic levels in the Coppin Gap Greenstone Belt suggests that extension played a role over a prolonged period of time. From about the deposition of the McPhee Formation at $\sim 3469$ Ma to the top of the Panorama Formation at $\sim 3446 \mathrm{Ma}$ (i.e. at least $20 \mathrm{Ma}$ ), there was either regular or continuous extension in the Coppin Gap Greenstone Belt. The extensional deformation may have even continued until the time of deposition of the Euro Basalt (Kloppenburg, 2003 and Bamboo Creek area depending on the age of the basalts), possibly until $\sim 3415 \mathrm{Ma}$.

\subsection{Cause of the extension}

The abundance of volcanic deposits, hydrothermal activity and the occurrence of normal faults in the Duffer Formation and KG-vsc, suggest that the extension may have been volcanism-related. However, the long duration of extension with a consistent orientation, and the regional occurrence of extension during deposition of the Warrawoona Group, make it unlikely that these structures relate to local collapse in the flanks of synvolcanic domes that were formed during the emplacement of subvolcanic sills or in the margins of calderas (which was suggested by e.g. Van Kranendonk et al. (2002)).

Collins (1989) suggested that the initial stages of doming of a large granite batholith in the Pilbara created a gradient sufficiently steep to initiate gravitational collapse. He used this to explain gravitational folding in the McPhee Reward area. However, the extension direction in the Coppin Gap Greenstone Belt is at right angles to the direction expected if the structures were related to doming of the adjacent granitoid complexes. Moreover, reconstruction of the original vergence of the near-surface extensional structures by Nijman and De Vries (2004), shows that throughout the East Pilbara the early extension structures are unrelated to the presentday locations of the granitoid complexes. Therefore, the extension cannot be explained as a result of doming of these batholiths. The reconstruction also shows that the structures do not fit a linear field of extension either. The interpreted large-scale, non-linear surficial collapse occurred along slope gradients persistent over a period of at least 20-50 Ma. A possible driver for such long-lived extension near the Earth's surface is deep-seated linear extension, such as that active in metamorphic core complexes (Zegers et al., 1996). However, a plate tectonic model for the extension seems unlikely without preceding orogenic thickening of the crust, for which there is no evidence. The combination of bimodal volcanic activity, non-linearity and upper crustal collapse may instead be explained as a result of local delamination processes in the lower crust (Nijman and De Vries, 2004; Zegers, 2004).

\subsection{Stratigraphic continuity or not?}

The shear zones in the Coppin Gap Greenstone Belt (and its westward extension towards the Marble Bar Greenstone Belt) have commonly had a multiphase history (e.g. Zegers et al., 1996; Nijman et al., 1998b; Van Haaften and White, 1998). Deformation within these shear zones may have influenced the stratigraphic thickness either in a negative (extensive) or a positive (compressive) sense. To establish whether the stratigraphic succession in the Coppin Gap Greenstone Belt is continuous, absolute dating of successions on either side of the shear zones is essential. The new SHRIMP U-Pb zircon dates presented herein (samples A-G, Fig. 1 and Table 2) have greatly increased the density of dates within this greenstone belt. Combined with existing dates from the Coppin Gap and the adjacent Marble Bar Greenstone Belt (Fig. 1 and Table 2, and references therein), the new dates confirm a general upward-younging of the stratigraphic succession in the Coppin Gap Greenstone Belt; the andesitic unit (sample D, Fig. 2; assigned to the Apex Formation by Williams, 1999) is slightly younger than the felsic part of the underlying Duffer Formation, and the Kittys Gap felsic volcanic complex may be assigned to the younger part of the Panorama Formation. Hence, even with the higher density of dates now available, there is no indication for duplication or excision of large sections of the stratigraphy of the Coppin Gap Greenstone Belt. The suggestion of Nijman et al. (1998b) that the felsic rocks of the P-assemblage could be a tectonic repetition of lower parts of Warrawoona stratigraphy is therefore rejected. This conclusion is confirmed by the geochemical data, which show that the felsic volcanic rocks of the Duffer and Panorama Formations are distinctly different.

Duplications of the stratigraphy on a smaller scale cannot be excluded, however. All dates from the main felsic unit of the Duffer Formation are within uncertainty of each other, which makes it is impossible to draw conclusions about the depositional ages of rocks at the different levels within the main felsic unit relative to each other. It is known, for example from Alpine-type collisional orogens, that tectonic juxtaposition through 
shortening may involve successions formed in only a few million years, i.e. smaller than the resolution of the dates (best resolution so far is $\pm 2 \mathrm{Ma}$, Table 2) in the Coppin Gap Greenstone Belt. Tectonic superposition on a scale of a few million years within greenstone belts of the Pilbara Craton cannot be excluded until the precision of the dates is improved. The same holds for excision of stratigraphic units. Only in one location excision could be established, namely in the western part of the study area, where the lowermost units of the Duffer Formation are absent below the F3 deformation zone.

\section{Conclusions}

1. Detailed analysis of the central part of the Coppin Gap Greenstone Belt of the East Pilbara (Australia) reveals the existence of superposed normal fault systems and bedding-parallel deformation zones in the early Archaean rock succession.

2. New stratigraphic observations, U-Pb zircon dates, and geochemical analyses do not show major duplications of the stratigraphic succession in the Coppin Gap Greenstone Belt. Nevertheless, the precision of the U-Pb SHRIMP dates cannot rule out duplications of stratigraphy on the order of a few million years, or loss of stratigraphic section due to excision. The latter occurs at least once, in the western part of the study area, where the lowermost part of the Duffer Formation is locally absent.

3. The early, often syndepositional deformation was primarily extensional, but locally also gave rise to compressive structures. The brittle, low-overburden style of deformation, and the nature of the associated compressive structures characterise the extension as being due to surficial (i.e. uppermost crustal) gravitational collapse.

4. Surficial gravitational collapse may result in a succession that shows overall stratigraphic continuity, as well as major deformation zones.

5. In the Coppin Gap Greenstone Belt the extension was consistently oriented east-west over a time interval of at least $20-50 \mathrm{Ma}$. This is at right angles to the direction expected if the extension would have been related to granitoid doming. Moreover, throughout the East Pilbara the early extension directions do not fit with granitoid doming.

6. The driving mechanism for the surficial gravitational collapse may have been deep-seated crustal delamination processes rather than processes related to plate tectonics, metamorphic core complex formation or multiphase diapirism of granitoid batholiths.

\section{Acknowledgements}

MSc students I.M.A. Vos, J.P.M. van der Meer, K.L. Louzada, T. Benedictus and S.H.J.M. van den Boorn participated in the fieldwork. J.P.M. van der Meer analysed the geochemistry samples discussed in this article as part of an undergraduate project at Utrecht University. Dr. M.J. van Bergen is thanked for advice on the geochemistry and volcanology. The Foundation Dr. Schürmannfonds supported part of the fieldwork with grants 2000/14, 2001/14 and 2002/10. U-Pb SHRIMP dating was carried out at Curtin University of Technology in Perth, and was financed with contributions from the Geodynamical Research Institute (GOI) to STdV and The Netherlands Organization for Scientific Research (NWO) to STdV (grant R 75-394) and JW. Comments on earlier versions of this manuscript by Prof. P.L. de Boer and Prof. M.J. de Wit were very helpful. Three anonymous reviewers are thanked for comments that helped to improve this article.

\section{Appendix A}

\section{A.1. Analytical technique}

Zircons were separated from 8 to $9 \mathrm{~kg}$ rock samples at the mineral separation laboratory of the Free University in Amsterdam. The samples were crushed and ground with a rock splitter, jaw crusher and disk mill to a size of $<500 \mu \mathrm{m}$. The samples were then sieved to obtain a fraction smaller than $250 \mu \mathrm{m}$. Light particles smaller than $32 \mu \mathrm{m}$ were removed. Zircons were separated from the remaining fraction using standard heavy liquid and magnetic separation techniques. The handpicked zircons, together with zircon standard CZ3 (Pidgeon et al., 1994), were mounted in epoxy resin and polished. Spots for analyses were selected using transmitted and reflected light microscopy images, as well as SEM cathodoluminescence images of the mounted zircons. Analyses were performed on the SHRIMP II at Curtin University of Technology in Perth, Australia. Operating procedures for $\mathrm{U}$, Th and $\mathrm{Pb}$ isotopic measurements on zircon are based on those described by Compston et al. (1984) and Williams et al. (1984). The data acquisition and processing were done as described in detail by Nelson $(1997,1999)$.

\section{A.2. Results}

\section{A.2.1. Sample A}

Sample A contains abundant zircons of $>90 \mu \mathrm{m}$. The zircons are light pink and very translucent. They are 
Table A1

Ion microprobe analytical results for sample A (original number VM00-255)

\begin{tabular}{|c|c|c|c|c|c|c|c|c|c|c|c|c|c|c|c|}
\hline $\begin{array}{l}\text { Grain } \\
\text { spot }\end{array}$ & $\begin{array}{l}\mathrm{U} \\
(\mathrm{ppm})\end{array}$ & $\begin{array}{l}\text { Th } \\
\text { (ppm) }\end{array}$ & $\begin{array}{l}\mathrm{Pb} \\
(\mathrm{ppm})\end{array}$ & $f_{206 \%}$ & ${ }^{207} \mathrm{~Pb} / 206 \mathrm{~Pb}$ & $\pm 1 \sigma$ & ${ }^{208} \mathrm{~Pb} /{ }^{206} \mathrm{~Pb}$ & $\pm 1 \sigma$ & ${ }^{206} \mathrm{~Pb} /{ }^{238} \mathrm{U}$ & $\pm 1 \sigma$ & ${ }^{207} \mathrm{~Pb} /{ }^{235} \mathrm{U}$ & $\pm 1 \sigma$ & $\begin{array}{l}\text { Concordance } \\
(\%)\end{array}$ & ${ }^{207} \mathrm{~Pb} /{ }^{206} \mathrm{~Pb}$ age & $\pm 1 \sigma$ \\
\hline $255-1.1$ & 236 & 180 & 215 & 0.076 & 0.30027 & 0.00121 & 0.20435 & 0.00142 & 0.7007 & 0.0191 & 29.010 & 0.812 & 99 & 3472 & 6 \\
\hline $255-2.1$ & 150 & 107 & 137 & 0.042 & 0.30066 & 0.00134 & 0.19251 & 0.00159 & 0.7076 & 0.0193 & 29.332 & 0.826 & 99 & 3474 & 7 \\
\hline $255-3.1$ & 263 & 259 & 246 & 0.087 & 0.30225 & 0.00098 & 0.26454 & 0.00126 & 0.6912 & 0.0187 & 28.805 & 0.795 & 97 & 3482 & 5 \\
\hline $255-4.1$ & 229 & 177 & 212 & 0.072 & 0.29851 & 0.00104 & 0.20625 & 0.00118 & 0.7134 & 0.0193 & 29.361 & 0.814 & 100 & 3462 & 5 \\
\hline $255-5.1$ & 223 & 170 & 198 & 0.022 & 0.29908 & 0.00102 & 0.20633 & 0.00120 & 0.6856 & 0.0185 & 28.270 & 0.782 & 97 & 3465 & 5 \\
\hline $255-6.1$ & 247 & 195 & 222 & 0.057 & 0.29930 & 0.00103 & 0.21040 & 0.00121 & 0.6928 & 0.0187 & 28.589 & 0.792 & 98 & 3467 & 5 \\
\hline $255-7.1$ & 125 & 83 & 111 & 0.180 & 0.30114 & 0.00150 & 0.17451 & 0.00185 & 0.6916 & 0.0189 & 28.715 & 0.815 & 97 & 3476 & 8 \\
\hline $255-8.1$ & 166 & 111 & 150 & 0.229 & 0.30034 & 0.00129 & 0.17674 & 0.00155 & 0.7058 & 0.0192 & 29.226 & 0.821 & 99 & 3472 & 7 \\
\hline $255-9.1$ & 162 & 113 & 139 & 0.193 & 0.29923 & 0.00132 & 0.18397 & 0.00158 & 0.6690 & 0.0182 & 27.603 & 0.775 & 95 & 3466 & 7 \\
\hline $255-10.1$ & 331 & 313 & 295 & 0.010 & 0.29882 & 0.00090 & 0.27113 & 0.00112 & 0.7010 & 0.0189 & 28.880 & 0.795 & 99 & 3464 & 5 \\
\hline $255-11.1$ & 233 & 185 & 218 & 0.120 & 0.30147 & 0.00109 & 0.21196 & 0.00133 & 0.7146 & 0.0194 & 29.702 & 0.826 & 100 & 3478 & 6 \\
\hline $255-12.1$ & 204 & 148 & 184 & 0.126 & 0.30062 & 0.00116 & 0.18957 & 0.00137 & 0.7004 & 0.0190 & 29.031 & 0.809 & 99 & 3473 & 6 \\
\hline $255-13.1$ & 240 & 190 & 220 & 0.042 & 0.30157 & 0.00107 & 0.21286 & 0.00122 & 0.7029 & 0.0191 & 29.227 & 0.812 & 99 & 3478 & 5 \\
\hline $255-14.1$ & 207 & 159 & 190 & 0.064 & 0.29905 & 0.00111 & 0.20326 & 0.00125 & 0.7103 & 0.0193 & 29.287 & 0.815 & 100 & 3465 & 6 \\
\hline $255-15.1$ & 267 & 225 & 248 & 0.052 & 0.29965 & 0.00101 & 0.22116 & 0.00120 & 0.7082 & 0.0192 & 29.260 & 0.810 & 100 & 3468 & 5 \\
\hline $255-16.1$ & 197 & 144 & 182 & 0.064 & 0.29990 & 0.00120 & 0.19492 & 0.00133 & 0.7148 & 0.0195 & 29.556 & 0.828 & 100 & 3470 & 6 \\
\hline $255-17.1$ & 193 & 152 & 177 & 0.059 & 0.29753 & 0.00118 & 0.20876 & 0.00140 & 0.7043 & 0.0191 & 28.893 & 0.807 & 99 & 3457 & 6 \\
\hline $255-18.1$ & 215 & 171 & 198 & 0.222 & 0.29896 & 0.00122 & 0.20769 & 0.00154 & 0.7040 & 0.0191 & 29.017 & 0.812 & 99 & 3465 & 6 \\
\hline $255-19.1$ & 285 & 295 & 275 & 0.133 & 0.29746 & 0.00077 & 0.27519 & 0.00104 & 0.7096 & 0.0106 & 29.101 & 0.452 & 100 & 3457 & 4 \\
\hline $255-20.1$ & 169 & 123 & 159 & 0.024 & 0.29848 & 0.00098 & 0.19445 & 0.00109 & 0.7317 & 0.0111 & 30.115 & 0.480 & 102 & 3462 & 5 \\
\hline $255-21.1$ & 148 & 89 & 136 & -0.022 & 0.29855 & 0.00104 & 0.15866 & 0.00106 & 0.7296 & 0.0111 & 30.032 & 0.482 & 102 & 3463 & 5 \\
\hline $255-22.1$ & 243 & 201 & 230 & 0.040 & 0.29897 & 0.00080 & 0.21922 & 0.00092 & 0.7219 & 0.0109 & 29.758 & 0.465 & 101 & 3465 & 4 \\
\hline $255-23.1$ & 299 & 245 & 283 & 0.035 & 0.29843 & 0.00074 & 0.21719 & 0.00083 & 0.7252 & 0.0109 & 29.839 & 0.463 & 102 & 3462 & 4 \\
\hline $255-24.1$ & 180 & 111 & 167 & 0.106 & 0.29613 & 0.00095 & 0.15926 & 0.00101 & 0.7390 & 0.0112 & 30.176 & 0.480 & 103 & 3450 & 5 \\
\hline $255-25.1$ & 180 & 116 & 167 & 0.076 & 0.29904 & 0.00095 & 0.17308 & 0.00099 & 0.7318 & 0.0111 & 30.174 & 0.479 & 102 & 3465 & 5 \\
\hline $255-26.1$ & 263 & 224 & 248 & 0.054 & 0.29898 & 0.00077 & 0.22415 & 0.00089 & 0.7170 & 0.0108 & 29.559 & 0.460 & 101 & 3465 & 4 \\
\hline $255-27.1$ & 207 & 172 & 191 & 0.094 & 0.29854 & 0.00087 & 0.21599 & 0.00102 & 0.7042 & 0.0106 & 28.986 & 0.455 & 99 & 3463 & 5 \\
\hline $255-28.1$ & 206 & 145 & 192 & 0.035 & 0.29575 & 0.00084 & 0.18693 & 0.00088 & 0.7288 & 0.0110 & 29.718 & 0.467 & 102 & 3448 & 4 \\
\hline $255-29.1$ & 288 & 289 & 280 & 0.035 & 0.29744 & 0.00072 & 0.26671 & 0.00090 & 0.7212 & 0.0108 & 29.577 & 0.458 & 101 & 3457 & 4 \\
\hline $255-30.1$ & 301 & 255 & 279 & 0.028 & 0.29712 & 0.00076 & 0.22929 & 0.00091 & 0.7052 & 0.0106 & 28.891 & 0.449 & 100 & 3455 & 4 \\
\hline
\end{tabular}


short, columnar and extremely euhedral shaped. The population is very homogeneous and contains only rarely more elongate, whitish-coloured zircons. Cathodoluminescence images show well developed, but on the images very faint, magmatic compositional zoning in about $75 \%$ of the zircons. The other zircons show no internal structure. Thirty analyses were made, all on different zircons (Table A1). 26 analyses together define a mean ${ }^{207} \mathrm{~Pb} /{ }^{206} \mathrm{~Pb}$ age of $3464 \pm 2 \mathrm{Ma}(95 \%$ confidence level; $\left.\chi^{2}=1.2\right)$. Four analyses were excluded from the age calculation because statistically they do not belong to the main group. Analyses 3.1 and 13.1 are slightly older, and may represent xenocrysts. Analyses 24.1 and 28.1 are slightly younger and reversely discordant. The age of $3464 \pm 2 \mathrm{Ma}$ is interpreted as the age of crystallisation of the quartz-plagioclase porphyry.

\section{A.2.2. Sample B}

Zircons of sample B are very much like the zircons of sample A. The translucent zircons are between 100 and $200 \mu \mathrm{m}$, and form a very heterogeneous population. The zircons are short and stubby, and very euhedral. Cathodoluminescence images reveal a well-developed but faintly visible magmatic zoning. A number of zircons are fractured, but these were avoided during analysis. Ten analyses were made, all on different zircons (Table A2). Together, these analyses define a mean ${ }^{207} \mathrm{~Pb} /{ }^{206} \mathrm{~Pb}$ age of $3465 \pm 4 \mathrm{Ma}$ ( $95 \%$ confidence level; $\chi^{2}=0.61$ ). This age is interpreted as the age of crystallisation of the quartz-plagioclase porphyry.

\section{A.2.3. Sample $C$}

Sample C contains abundant zircons of $>90 \mu \mathrm{m}$. The zircons are translucent, and pink to reddish-coloured. There are two different shapes of zircons; elongate ones with a long $c$-axis, and more round ones, with a $c$-axis that is only slightly longer than the short axis of the zircons. On cathodoluminescence images, most zircons display a clear magmatic zoning. Some zircon grains have a distinct core. Thirty analyses were made, all on different zircons (Table A3). Together, these analyses define a mean ${ }^{207} \mathrm{~Pb} /{ }^{206} \mathrm{~Pb}$ age of $3465 \pm 4 \mathrm{Ma}$ (95\% confidence level; $\chi^{2}=1.23$ ). This age is interpreted as the age of crystallisation of the plagioclase porphyry.

\section{A.2.4. Sample $D$}

Sample D contains only a few zircons of $>90 \mu \mathrm{m}$, most zircons are between 60 and $90 \mu \mathrm{m}$ in size. Most zircons are colourless to purple, and are not very translucent. The outlines of the zircons are rough and the surfaces are pockmarked. Euhedral zircons are rare.

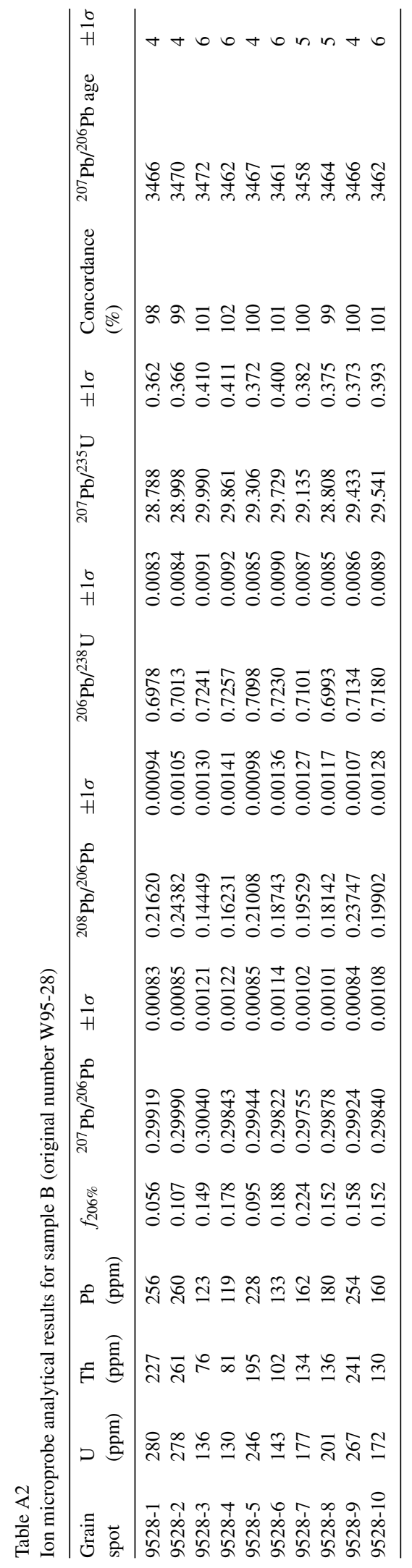


Table A3

Ion microprobe analytical results for sample C (original number W98-5)

\begin{tabular}{|c|c|c|c|c|c|c|c|c|c|c|c|c|c|c|c|}
\hline $\begin{array}{l}\text { Grain } \\
\text { spot }\end{array}$ & $\begin{array}{l}\mathrm{U} \\
(\mathrm{ppm})\end{array}$ & $\begin{array}{l}\text { Th } \\
\text { (ppm) }\end{array}$ & $\begin{array}{l}\mathrm{Pb} \\
(\mathrm{ppm})\end{array}$ & $f_{206 \%}$ & ${ }^{207} \mathrm{~Pb} /{ }^{206} \mathrm{~Pb}$ & $\pm 1 \sigma$ & ${ }^{208} \mathrm{~Pb} / 206 \mathrm{~Pb}$ & $\pm 1 \sigma$ & ${ }^{206} \mathrm{~Pb} /{ }^{238} \mathrm{U}$ & $\pm 1 \sigma$ & ${ }^{207} \mathrm{~Pb} /{ }^{235} \mathrm{U}$ & $\pm 1 \sigma$ & $\begin{array}{l}\text { Concordance } \\
(\%)\end{array}$ & ${ }^{207} \mathrm{~Pb} /{ }^{206} \mathrm{~Pb}$ age & $\pm 1 \sigma$ \\
\hline W98-1.1 & 67 & 51 & 67 & 0.295 & 0.29672 & 0.00281 & 0.19386 & 0.00422 & 0.7703 & 0.0220 & 31.513 & 0.983 & 107 & 3453 & 15 \\
\hline W98-2.1 & 107 & 115 & 108 & 0.112 & 0.29878 & 0.00168 & 0.28345 & 0.00241 & 0.7373 & 0.0203 & 30.375 & 0.875 & 103 & 3464 & 9 \\
\hline W98-3.1 & 100 & 105 & 101 & 0.126 & 0.30117 & 0.00169 & 0.27816 & 0.00234 & 0.7380 & 0.0204 & 30.645 & 0.885 & 102 & 3476 & 9 \\
\hline W98-4.1 & 59 & 48 & 58 & 0.154 & 0.30064 & 0.00225 & 0.21244 & 0.00310 & 0.7456 & 0.0210 & 30.908 & 0.928 & 103 & 3474 & 12 \\
\hline W98-5.1 & 94 & 100 & 94 & 0.036 & 0.30163 & 0.00180 & 0.28476 & 0.00237 & 0.7317 & 0.0203 & 30.431 & 0.887 & 102 & 3479 & 9 \\
\hline W98-6.1 & 83 & 88 & 85 & -0.014 & 0.30161 & 0.00192 & 0.29047 & 0.00260 & 0.7505 & 0.0209 & 31.212 & 0.916 & 104 & 3479 & 10 \\
\hline W98-7.1 & 103 & 106 & 110 & 0.008 & 0.30275 & 0.00194 & 0.28101 & 0.00239 & 0.7832 & 0.0219 & 32.695 & 0.961 & 107 & 3484 & 10 \\
\hline W98-8.1 & 74 & 58 & 68 & -0.044 & 0.30264 & 0.00187 & 0.21179 & 0.00244 & 0.7061 & 0.0196 & 29.463 & 0.859 & 99 & 3484 & 10 \\
\hline W98-9.1 & 41 & 35 & 39 & 0.336 & 0.30036 & 0.00272 & 0.23612 & 0.00404 & 0.7157 & 0.0205 & 29.639 & 0.921 & 100 & 3472 & 14 \\
\hline W98-10.1 & 68 & 62 & 66 & 0.092 & 0.29934 & 0.00192 & 0.24042 & 0.00260 & 0.7293 & 0.0203 & 30.103 & 0.884 & 102 & 3467 & 10 \\
\hline W98-11.1 & 85 & 80 & 82 & 0.108 & 0.30014 & 0.00174 & 0.25777 & 0.00240 & 0.7153 & 0.0198 & 29.603 & 0.857 & 100 & 3471 & 9 \\
\hline W98-12.1 & 120 & 127 & 116 & 0.154 & 0.29968 & 0.00144 & 0.28507 & 0.00197 & 0.7075 & 0.0194 & 29.234 & 0.829 & 99 & 3469 & 7 \\
\hline W98-13.1 & 72 & 67 & 70 & 0.272 & 0.30089 & 0.00193 & 0.25072 & 0.00274 & 0.7171 & 0.0199 & 29.749 & 0.872 & 100 & 3475 & 10 \\
\hline W98-14.1 & 60 & 44 & 55 & 0.382 & 0.29458 & 0.00214 & 0.19080 & 0.00291 & 0.7038 & 0.0197 & 28.585 & 0.853 & 100 & 3442 & 11 \\
\hline W98-15.1 & 61 & 50 & 57 & 0.019 & 0.29918 & 0.00190 & 0.21500 & 0.00214 & 0.7156 & 0.0200 & 29.519 & 0.869 & 100 & 3466 & 10 \\
\hline W98-16.1 & 69 & 57 & 64 & 0.315 & 0.29773 & 0.00199 & 0.21765 & 0.00285 & 0.7018 & 0.0195 & 28.808 & 0.847 & 99 & 3458 & 10 \\
\hline W98-17.1 & 145 & 138 & 138 & 0.037 & 0.29812 & 0.00103 & 0.25008 & 0.00127 & 0.7136 & 0.0109 & 29.332 & 0.470 & 100 & 3460 & 5 \\
\hline W98-18.1 & 59 & 43 & 56 & 0.115 & 0.29654 & 0.00169 & 0.18296 & 0.00196 & 0.7466 & 0.0119 & 30.527 & 0.539 & 104 & 3452 & 9 \\
\hline W98-19.1 & 75 & 70 & 74 & 0.015 & 0.29881 & 0.00146 & 0.24495 & 0.00175 & 0.7369 & 0.0116 & 30.360 & 0.517 & 103 & 3464 & 8 \\
\hline W98-20.1 & 77 & 77 & 77 & 0.117 & 0.29766 & 0.00147 & 0.26660 & 0.00207 & 0.7411 & 0.0117 & 30.414 & 0.519 & 103 & 3458 & 8 \\
\hline W98-21.1 & 61 & 40 & 57 & 0.118 & 0.30048 & 0.00165 & 0.17628 & 0.00192 & 0.7329 & 0.0117 & 30.365 & 0.530 & 102 & 3473 & 8 \\
\hline W98-22.1 & 83 & 92 & 82 & 0.069 & 0.29712 & 0.00139 & 0.29123 & 0.00195 & 0.7266 & 0.0113 & 29.766 & 0.501 & 102 & 3455 & 7 \\
\hline W98-23.1 & 66 & 51 & 62 & 0.096 & 0.29926 & 0.00155 & 0.20596 & 0.00188 & 0.7253 & 0.0114 & 29.929 & 0.515 & 101 & 3466 & 8 \\
\hline W98-24.1 & 80 & 79 & 75 & 0.099 & 0.29604 & 0.00144 & 0.26216 & 0.00198 & 0.6916 & 0.0107 & 28.230 & 0.473 & 98 & 3450 & 8 \\
\hline W98-25.1 & 101 & 114 & 102 & -0.012 & 0.30116 & 0.00134 & 0.30044 & 0.00189 & 0.7350 & 0.0114 & 30.521 & 0.509 & 102 & 3476 & 7 \\
\hline W98-26.1 & 92 & 97 & 92 & 0.015 & 0.29891 & 0.00132 & 0.27981 & 0.00170 & 0.7291 & 0.0113 & 30.049 & 0.502 & 102 & 3465 & 7 \\
\hline W98-27.1 & 82 & 68 & 78 & 0.054 & 0.29711 & 0.00140 & 0.22115 & 0.00173 & 0.7257 & 0.0113 & 29.728 & 0.501 & 102 & 3455 & 7 \\
\hline W98-28.1 & 93 & 96 & 92 & 0.115 & 0.29780 & 0.00133 & 0.27700 & 0.00180 & 0.7221 & 0.0112 & 29.652 & 0.495 & 101 & 3459 & 7 \\
\hline W98-29.1 & 66 & 51 & 64 & 0.081 & 0.29936 & 0.00162 & 0.20904 & 0.00206 & 0.7470 & 0.0119 & 30.831 & 0.537 & 104 & 3467 & 8 \\
\hline W98-30.1 & 139 & 141 & 140 & 0.048 & 0.29923 & 0.00108 & 0.27369 & 0.00139 & 0.7460 & 0.0114 & 30.777 & 0.497 & 104 & 3466 & 6 \\
\hline
\end{tabular}


Table A4

Ion microprobe analytical results for sample D (original number VM00-124)

\begin{tabular}{|c|c|c|c|c|c|c|c|c|c|c|c|c|c|c|c|}
\hline $\begin{array}{l}\text { Grain } \\
\text { spot }\end{array}$ & $\begin{array}{l}\mathrm{U} \\
(\mathrm{ppm})\end{array}$ & $\begin{array}{l}\text { Th } \\
\text { (ppm) }\end{array}$ & $\begin{array}{l}\mathrm{Pb} \\
(\mathrm{ppm})\end{array}$ & $f_{206 \%}$ & ${ }^{207} \mathrm{~Pb} /{ }^{206} \mathrm{~Pb}$ & $\pm 1 \sigma$ & ${ }^{208} \mathrm{~Pb} /{ }^{206} \mathrm{~Pb}$ & $\pm 1 \sigma$ & ${ }^{206} \mathrm{~Pb} /{ }^{238} \mathrm{U}$ & $\pm 1 \sigma$ & ${ }^{207} \mathrm{~Pb} /{ }^{235} \mathrm{U}$ & $\pm 1 \sigma$ & $\begin{array}{l}\text { Concordance } \\
(\%)\end{array}$ & ${ }^{207} \mathrm{~Pb} /{ }^{206} \mathrm{~Pb}$ age & $\pm 1 \sigma$ \\
\hline $124-1.1$ & 250 & 207 & 226 & 0.123 & 0.29945 & 0.00068 & 0.22255 & 0.00086 & 0.6880 & 0.0071 & 28.407 & 0.307 & 97 & 3467 & 4 \\
\hline $124-2.1$ & 142 & 91 & 129 & 0.099 & 0.29862 & 0.00091 & 0.16987 & 0.00102 & 0.7169 & 0.0076 & 29.520 & 0.336 & 101 & 3463 & 5 \\
\hline $124-3.1$ & 321 & 384 & 307 & 0.120 & 0.29740 & 0.00058 & 0.31472 & 0.00082 & 0.6860 & 0.0070 & 28.127 & 0.300 & 97 & 3457 & 3 \\
\hline $124-4.1$ & 171 & 120 & 152 & 0.124 & 0.29944 & 0.00084 & 0.18678 & 0.00097 & 0.6888 & 0.0072 & 28.440 & 0.319 & 97 & 3467 & 4 \\
\hline $124-5.1$ & 211 & 168 & 196 & 0.101 & 0.29665 & 0.00091 & 0.20945 & 0.00104 & 0.7128 & 0.0109 & 29.157 & 0.464 & 100 & 3453 & 5 \\
\hline $124-6.1$ & 152 & 109 & 140 & 0.177 & 0.29751 & 0.00112 & 0.19007 & 0.00138 & 0.7160 & 0.0110 & 29.370 & 0.478 & 101 & 3457 & 6 \\
\hline $124-7.1$ & 246 & 174 & 210 & 0.060 & 0.29496 & 0.00079 & 0.18622 & 0.00089 & 0.6694 & 0.0101 & 27.226 & 0.426 & 96 & 3444 & 4 \\
\hline $124-8.1$ & 515 & 800 & 443 & 0.135 & 0.28157 & 0.00046 & 0.41481 & 0.00079 & 0.5870 & 0.0087 & 22.791 & 0.346 & 88 & 3372 & 3 \\
\hline $124-9.1$ & 179 & 118 & 162 & 0.059 & 0.29779 & 0.00079 & 0.17549 & 0.00083 & 0.7120 & 0.0108 & 29.236 & 0.458 & 100 & 3459 & 4 \\
\hline $124-10.1$ & 326 & 297 & 257 & 0.120 & 0.28479 & 0.00064 & 0.20701 & 0.00078 & 0.6103 & 0.0091 & 23.965 & 0.369 & 91 & 3389 & 3 \\
\hline $124-11.1$ & 244 & 306 & 244 & 0.106 & 0.29656 & 0.00088 & 0.32662 & 0.00130 & 0.7139 & 0.0109 & 29.190 & 0.463 & 101 & 3452 & 5 \\
\hline $124-12.1$ & 376 & 321 & 299 & 0.121 & 0.29110 & 0.00079 & 0.21466 & 0.00098 & 0.6115 & 0.0092 & 24.545 & 0.383 & 90 & 3423 & 4 \\
\hline $124-13.1$ & 278 & 215 & 253 & 0.429 & 0.29737 & 0.00092 & 0.19805 & 0.00128 & 0.6974 & 0.0106 & 28.595 & 0.453 & 99 & 3457 & 5 \\
\hline $124-14.1$ & 534 & 842 & 470 & 0.115 & 0.28723 & 0.00065 & 0.41988 & 0.00110 & 0.5963 & 0.0089 & 23.617 & 0.364 & 89 & 3403 & 4 \\
\hline $124-15.1$ & 218 & 226 & 207 & 0.030 & 0.29922 & 0.00091 & 0.26879 & 0.00116 & 0.7020 & 0.0107 & 28.961 & 0.461 & 99 & 3466 & 5 \\
\hline $124-16.1$ & 211 & 143 & 187 & 0.138 & 0.29754 & 0.00096 & 0.18453 & 0.00112 & 0.6930 & 0.0106 & 28.432 & 0.455 & 98 & 3457 & 5 \\
\hline $124-17.1$ & 160 & 118 & 145 & 0.437 & 0.29471 & 0.00123 & 0.20223 & 0.00180 & 0.6974 & 0.0107 & 28.340 & 0.467 & 99 & 3443 & 6 \\
\hline $124-18.1$ & 295 & 418 & 290 & 0.094 & 0.29915 & 0.00081 & 0.35916 & 0.00122 & 0.6865 & 0.0104 & 28.315 & 0.444 & 97 & 3466 & 4 \\
\hline $124-19.1$ & 592 & 524 & 549 & 0.026 & 0.29759 & 0.00049 & 0.23278 & 0.00055 & 0.7033 & 0.0105 & 28.858 & 0.439 & 99 & 3458 & 3 \\
\hline $124-20.1$ & 358 & 247 & 315 & 0.143 & 0.29656 & 0.00065 & 0.19730 & 0.00078 & 0.6811 & 0.0102 & 27.850 & 0.430 & 97 & 3452 & 3 \\
\hline $124-21.1$ & 263 & 230 & 248 & 0.100 & 0.29752 & 0.00077 & 0.23691 & 0.00100 & 0.7108 & 0.0107 & 29.157 & 0.456 & 100 & 3457 & 4 \\
\hline $124-22.1$ & 244 & 179 & 220 & 0.039 & 0.29810 & 0.00078 & 0.19347 & 0.00084 & 0.7029 & 0.0106 & 28.890 & 0.452 & 99 & 3460 & 4 \\
\hline $124-23.1$ & 246 & 183 & 220 & 0.063 & 0.29774 & 0.00079 & 0.19031 & 0.00085 & 0.6961 & 0.0105 & 28.577 & 0.448 & 98 & 3459 & 4 \\
\hline $124-24.1$ & 176 & 109 & 156 & 0.063 & 0.29767 & 0.00092 & 0.16327 & 0.00095 & 0.7041 & 0.0107 & 28.898 & 0.460 & 99 & 3458 & 5 \\
\hline $124-25.1$ & 755 & 776 & 504 & 0.100 & 0.27057 & 0.00052 & 0.26710 & 0.00072 & 0.5028 & 0.0075 & 18.756 & 0.286 & 79 & 3309 & 3 \\
\hline $124-26.1$ & 1196 & 2196 & 697 & 0.053 & 0.24871 & 0.00046 & 0.45642 & 0.00088 & 0.3962 & 0.0059 & 13.586 & 0.207 & 68 & 3177 & 3 \\
\hline $124-27.1$ & 306 & 245 & 280 & 0.140 & 0.29775 & 0.00078 & 0.22764 & 0.00098 & 0.6937 & 0.0105 & 28.479 & 0.445 & 98 & 3459 & 4 \\
\hline $124-22.2$ & 261 & 229 & 241 & 0.117 & 0.29826 & 0.00078 & 0.22955 & 0.00096 & 0.7003 & 0.0106 & 28.800 & 0.450 & 99 & 3461 & 4 \\
\hline $124-16.2$ & 2023 & 4061 & 1538 & 0.060 & 0.25426 & 0.00031 & 0.53995 & 0.00065 & 0.4905 & 0.0073 & 17.196 & 0.259 & 80 & 3211 & 2 \\
\hline $124-17.2$ & 162 & 96 & 144 & 0.157 & 0.29827 & 0.00101 & 0.16319 & 0.00113 & 0.7063 & 0.0108 & 29.049 & 0.468 & 100 & 3461 & 5 \\
\hline
\end{tabular}


Internally, many zircons are fractured and have small inclusions. Magmatic zoning is well visible on cathodoluminescence images. Thirty analyses were made on 27 different zircons (Table A4). Twenty-six analyses together define a mean ${ }^{207} \mathrm{~Pb} /{ }^{206} \mathrm{~Pb}$ age of $3459 \pm 2 \mathrm{Ma}$ (95\% confidence level; $\chi^{2}=1.42$ ). Eight highly discordant analyses were excluded from the age calculation. The age of $3459 \pm 2 \mathrm{Ma}$ is interpreted as the age of crystallisation of the plagioclase porphyry.

\section{A.2.5. Sample E}

The total zircon population of sample E looks rather inhomogeneous. Apart from nicely euhedral zircons, there are also subhedral ones, and many fragments. Part of the euhedral zircons displays clear magmatic zoning. Most zircons or fragments of zircons are between 100 and $200 \mu \mathrm{m}$. Both strongly elongated as well as more rounded zircons are present. Most zircons are transparent, some are fractured or have a pockmarked surface. 10 analyses were made, all on different zircons (Table A5). Eight analyses together define a mean ${ }^{207} \mathrm{~Pb} /{ }^{206} \mathrm{~Pb}$ age of $3446 \pm 5 \mathrm{Ma}\left(95 \%\right.$ confidence level; $\left.\chi^{2}=0.44\right)$. Two analyses fall statistically outside the main group. They are older, and give a combined age of $3473 \pm 6 \mathrm{Ma}$. They most probably represent xenocrysts. $3446 \pm 5 \mathrm{Ma}$ is interpreted as the age of crystallisation of the rhyolite.

\section{A.2.6. Sample $F$}

The zircon population in sample $F$ is extremely heterogeneous. There is a wide range of colours. The fraction of $>90 \mu \mathrm{m}$ contains translucent as well as milkywhite, non-translucent zircons. Zircons in the 60-90 $\mu \mathrm{m}$ fraction are frequently stained with a rust-colour. The shape of the zircons ranges from very elongate to short and stubby, and the crystals are euhedral to anhedral. Fragments of zircons are abundant. The most transparent zircons were used for analysis. The cathodoluminescence images of the zircons show the same heterogeneity. Some zircons are magmatically zoned, while others show no internal structure at all. Twenty-five analyses were made on 17 different zircons (Table A6). Ten analyses together define a mean ${ }^{207} \mathrm{~Pb} /{ }^{206} \mathrm{~Pb}$ age of $3459 \pm 4 \mathrm{Ma}\left(95 \%\right.$ confidence level; $\left.\chi^{2}=1.12\right)$. Two other groups of analyses show significantly younger ages. Four analyses combine together to an age of $3280 \pm 13 \mathrm{Ma}\left(95 \%\right.$ confidence level; $\left.\chi^{2}=0.82\right)$. Two other analyses give a combined age of $3352 \pm 4 \mathrm{Ma}$ ( $\pm 1 \sigma$ error). However, apart from two slightly reversely discordant analyses, all analyses making up the latter two groups are highly discordant, as are the remaining 7 analyses. The abundance of zircons with an age of $3459 \pm 4 \mathrm{Ma}$ is an indication of the age of the main

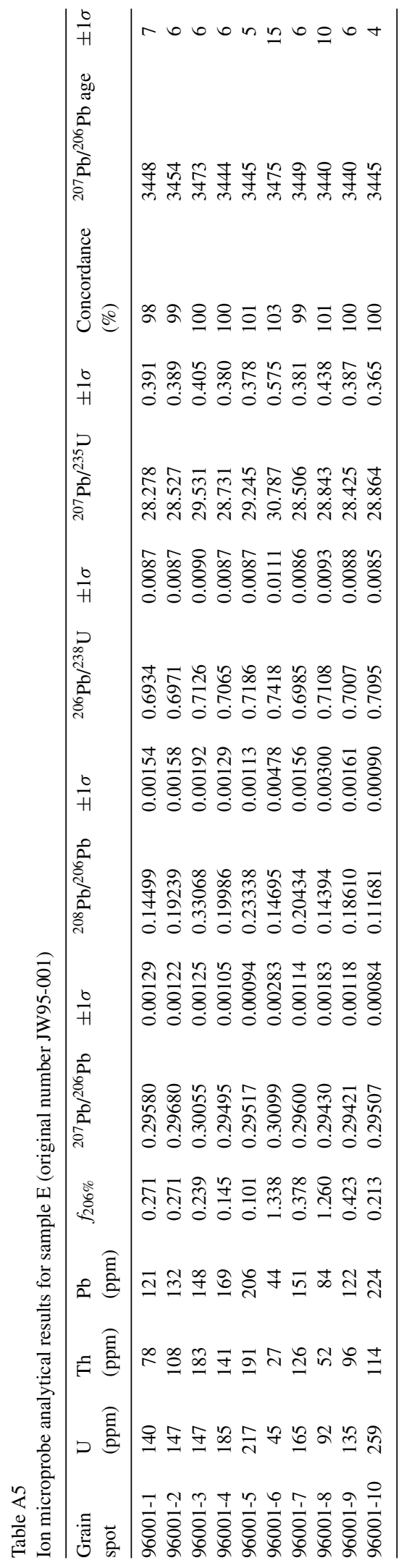


Table A6

Ion microprobe analytical results for sample F (original number W94-22.3)

\begin{tabular}{|c|c|c|c|c|c|c|c|c|c|c|c|c|c|c|c|}
\hline $\begin{array}{l}\text { Grain } \\
\text { spot }\end{array}$ & $\begin{array}{l}\mathrm{U} \\
(\mathrm{ppm})\end{array}$ & $\begin{array}{l}\text { Th } \\
(\mathrm{ppm})\end{array}$ & $\begin{array}{l}\mathrm{Pb} \\
(\mathrm{ppm})\end{array}$ & $f_{206 \%}$ & ${ }^{207} \mathrm{~Pb} /{ }^{206} \mathrm{~Pb}$ & $\pm 1 \sigma$ & ${ }^{208} \mathrm{~Pb} /{ }^{206} \mathrm{~Pb}$ & $\pm 1 \sigma$ & ${ }^{206} \mathrm{~Pb} /{ }^{238} \mathrm{U}$ & $\pm 1 \sigma$ & ${ }^{207} \mathrm{~Pb} /{ }^{235} \mathrm{U}$ & $\pm 1 \sigma$ & $\begin{array}{l}\text { Concordance } \\
(\%)\end{array}$ & ${ }^{207} \mathrm{~Pb} /{ }^{206} \mathrm{~Pb}$ age & $\pm 1 \sigma$ \\
\hline w94-1.1 & 300 & 310 & 145 & 4.078 & 0.29604 & 0.00236 & 0.16414 & 0.00469 & 0.3360 & 0.0036 & 13.714 & 0.193 & 54 & 3450 & 12 \\
\hline w94-2.1 & 172 & 84 & 41 & 0.311 & 0.08427 & 0.00135 & 0.14664 & 0.00289 & 0.2250 & 0.0024 & 2.614 & 0.053 & 101 & 1299 & 31 \\
\hline w94-3.1 & 42 & 159 & 17 & 3.834 & 0.08223 & 0.00686 & 1.14164 & 0.02125 & 0.1999 & 0.0027 & 2.266 & 0.195 & 94 & 1251 & 164 \\
\hline w94-4.1 & 212 & 167 & 202 & 0.116 & 0.29784 & 0.00096 & 0.20910 & 0.00112 & 0.7323 & 0.0079 & 30.072 & 0.349 & 102 & 3459 & 5 \\
\hline w94-5.1 & 165 & 31 & 119 & 0.394 & 0.29712 & 0.00129 & 0.04400 & 0.00150 & 0.6179 & 0.0068 & 25.314 & 0.310 & 90 & 3455 & 7 \\
\hline w94-6.1 & 173 & 115 & 121 & 0.384 & 0.26549 & 0.00122 & 0.19077 & 0.00173 & 0.5505 & 0.0060 & 20.151 & 0.248 & 86 & 3280 & 7 \\
\hline w94-7.1 & 195 & 150 & 180 & 0.082 & 0.29955 & 0.00101 & 0.20653 & 0.00114 & 0.7113 & 0.0077 & 29.380 & 0.345 & 100 & 3468 & 5 \\
\hline w94-8.1 & 1127 & 431 & 503 & 0.390 & 0.18886 & 0.00049 & 0.09879 & 0.00073 & 0.3975 & 0.0040 & 10.350 & 0.112 & 79 & 2732 & 4 \\
\hline W94-9.1 & 355 & 311 & 337 & 0.179 & 0.29813 & 0.00082 & 0.23005 & 0.00105 & 0.7178 & 0.0075 & 29.505 & 0.330 & 101 & 3461 & 4 \\
\hline w94-10.1 & 569 & 227 & 306 & 0.478 & 0.22299 & 0.00071 & 0.10088 & 0.00107 & 0.4639 & 0.0048 & 14.263 & 0.158 & 82 & 3002 & 5 \\
\hline w94-11.1 & 273 & 219 & 184 & 0.095 & 0.19254 & 0.00080 & 0.22144 & 0.00129 & 0.5524 & 0.0059 & 14.666 & 0.174 & 103 & 2764 & 7 \\
\hline w94-12.1 & 282 & 98 & 94 & 0.214 & 0.10726 & 0.00077 & 0.10265 & 0.00131 & 0.3176 & 0.0033 & 4.697 & 0.063 & 101 & 1753 & 13 \\
\hline w94-13.1 & 426 & 625 & 243 & 0.620 & 0.26703 & 0.00131 & 0.25965 & 0.00220 & 0.4246 & 0.0064 & 15.631 & 0.257 & 69 & 3289 & 8 \\
\hline w94-4.2 & 187 & 138 & 180 & 0.411 & 0.29818 & 0.00111 & 0.19969 & 0.00155 & 0.7377 & 0.0112 & 30.328 & 0.488 & 103 & 3461 & 6 \\
\hline w94-7.2 & 269 & 245 & 263 & 0.123 & 0.29792 & 0.00090 & 0.23874 & 0.00112 & 0.7370 & 0.0111 & 30.274 & 0.476 & 103 & 3459 & 5 \\
\hline w94-1.2 & 137 & 73 & 109 & 1.196 & 0.29532 & 0.00173 & 0.12631 & 0.00283 & 0.6284 & 0.0097 & 25.587 & 0.438 & 91 & 3446 & 9 \\
\hline w94-5.2 & 773 & 153 & 582 & 0.510 & 0.29397 & 0.00061 & 0.05282 & 0.00076 & 0.6377 & 0.0095 & 25.846 & 0.394 & 92 & 3439 & 3 \\
\hline w94-14.1 & 176 & 106 & 154 & 0.102 & 0.27787 & 0.00099 & 0.16118 & 0.00112 & 0.7046 & 0.0107 & 26.996 & 0.433 & 103 & 3351 & 6 \\
\hline w94-15.1 & 258 & 198 & 254 & 0.131 & 0.29625 & 0.00093 & 0.20135 & 0.00109 & 0.7622 & 0.0115 & 31.132 & 0.492 & 106 & 3451 & 5 \\
\hline w94-7.3 & 219 & 166 & 214 & 0.080 & 0.29918 & 0.00095 & 0.19795 & 0.00108 & 0.7576 & 0.0115 & 31.251 & 0.496 & 105 & 3466 & 5 \\
\hline w94-16.1 & 269 & 107 & 232 & 1.081 & 0.26533 & 0.00122 & 0.12447 & 0.00203 & 0.6965 & 0.0105 & 25.482 & 0.417 & 104 & 3279 & 7 \\
\hline w94-5.3 & 246 & 48 & 142 & 0.330 & 0.27835 & 0.00107 & 0.05166 & 0.00126 & 0.4991 & 0.0075 & 19.155 & 0.305 & 78 & 3354 & 6 \\
\hline w94-5.4 & 455 & 172 & 329 & 0.165 & 0.29174 & 0.00076 & 0.08860 & 0.00078 & 0.6054 & 0.0090 & 24.352 & 0.377 & 89 & 3427 & 4 \\
\hline w94-5.5 & 477 & 115 & 326 & 0.547 & 0.29119 & 0.00082 & 0.05733 & 0.00106 & 0.5771 & 0.0086 & 23.169 & 0.360 & 86 & 3424 & 4 \\
\hline w94-17.1 & 266 & 195 & 99 & 1.784 & 0.26333 & 0.00173 & 0.20896 & 0.00323 & 0.2770 & 0.0042 & 10.059 & 0.172 & 48 & 3267 & 10 \\
\hline
\end{tabular}




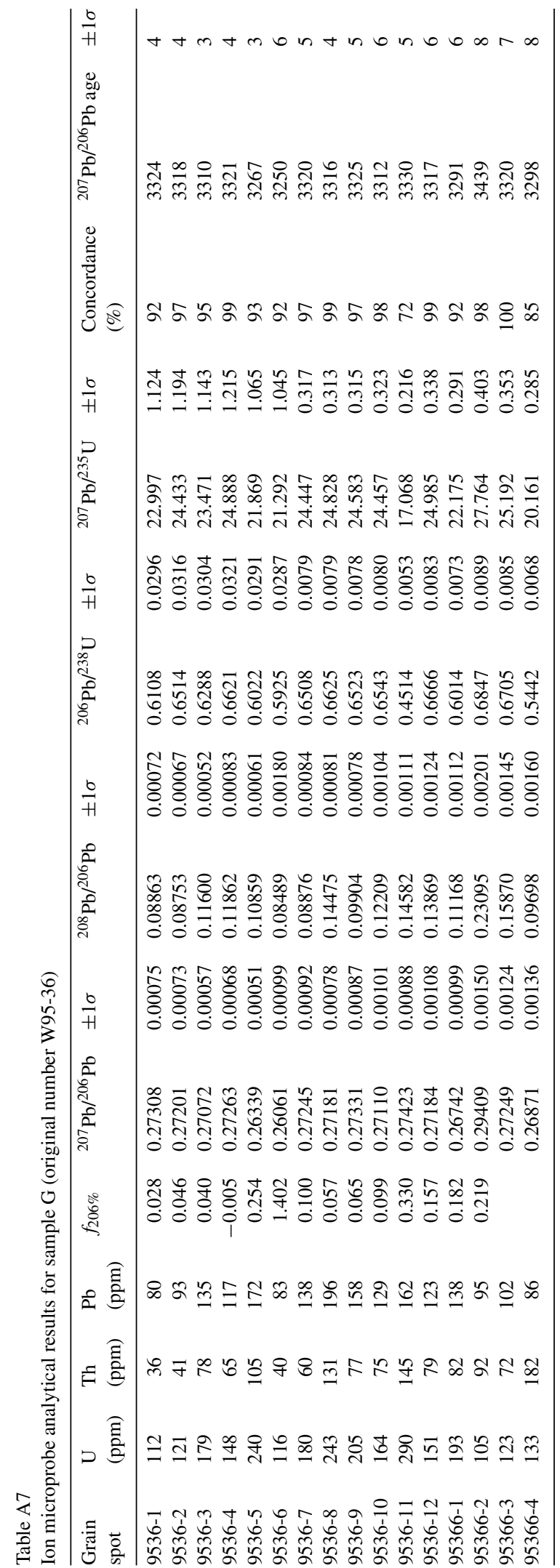

source area for this metasediment. The sedimentary rock is therefore definitely younger than $3459 \pm 4 \mathrm{Ma}$. Probably, it is younger than $3352 \pm 4 \mathrm{Ma}$, and maybe even younger than $3280 \pm 13 \mathrm{Ma}$. However, the exact maximum age is difficult to establish, because the analyses combining to the latter two dates are highly discordant.

\section{A.2.7. Sample $G$}

Sample G displays a very homogeneous zircon population. The zircons are nicely translucent, and range in size from 100 to $200 \mu \mathrm{m}$. They are slightly elongate, and are very euhedral. Cathodoluminescence imaging shows that the zircons are magmatically zoned. Many zircons show a core. Twelve analyses were made, all on different zircons (Table A7). Nine analyses together define a mean ${ }^{207} \mathrm{~Pb} /{ }^{206} \mathrm{~Pb}$ age of $3318 \pm 4 \mathrm{Ma}(95 \%$ confidence level; $\chi^{2}=1.28$ ). Three analyses fall statistically outside the main group. Two of those are slightly discordant, and have probably suffered some lead loss early in history. The age of $3318 \pm 4 \mathrm{Ma}$ is interpreted as the age of crystallisation of the felsic porphyry.

\section{References}

Barley, M.E., Loader, S.E., McNaughton, N.J., 1998. 3430 to 3417 Ma calc-alkaline volcanism in the McPhee Dome and Kelly Belt, and growth of the eastern Pilbara Craton. Precambrian Res. 88, 3-23.

Beintema, K.A., 2003. Geodynamic evolution of the West and Central Pilbara Craton in Western Australia: a mid-Archaean active continental margin. Geologica Ultraiectina 232, 248 pp.

Collins, W.J., 1989. Polydiapirism of the Archean Mount Edgar batholith, Pilbara block, Western Australia. Precambrian Res. 43, 41-62.

Compston, W., Williams, I.S., Meyer, C., 1984. U-Pb geochronology of zircons from lunar breccia 73217 using a sensitive high mass-resolution ion microprobe. J. Geophys. Res. B 89 (Suppl.), 525-534.

De Vries, S.T., Nijman, W., De Boer, P.L., 2006. Early Archaean sedimentary rocks of the Buck Ridge (South Africa) and Kittys Gap (Western Australia) volcano-sedimentary complexes. Sedimentology, in preparation.

De Wit, M.J., 1998. On Archean granites, greenstones, cratons and tectonics: does the evidence demand a verdict? Precambrian Res. 91, 181-226.

DiMarco, M.J., Lowe, D.R., 1989a. Shallow-water volcaniclastic deposition in the Early Archean Panorama Formation, Warrawoona Group, eastern Pilbara Block, Western Australia. Sediment. Geol. 64, 43-63.

DiMarco, M.J., Lowe, D.R., 1989b. Stratigraphy and sedimentology of an Early Archean felsic volcanic sequence, Eastern Pilbara Block, Western Australia, with special reference to the Duffer Formation and implications for crustal evolution. Precambrian Res. 44, $147-169$.

Hamilton, W.B., 1998. Archean magmatism and deformation were not products of plate tectonics. Precambrian Res. 91, 143-179. 
Hickman, A.H., 1983. Geology of the Pilbara Block and its environs. Geological Survey of Western Australia Bulletin 127, $268 \mathrm{pp}$.

Kloppenburg, A., 2003. Structural evolution of the Marble Bar Domain, Pilbara granite-greenstone terrain, Australia: the role of Archaean mid-crustal detachments. Geologica Ultraiectina 237, $256 \mathrm{pp}$.

Mandl, G., Crans, W., 1981. Gravitational gliding in deltas. In: McClay, K.R., Price, N.J. (Eds.), Thrust and Nappe Tectonics. Geol. Soc. Spec. Publ. 82, 41-54.

McNaughton, N.J., Compston, W., Barley, M.E., 1993. Constraints on the age of the Warrawoona Group, eastern Pilbara Block, Western Australia. Precambrian Res. 60, 69-98.

Nakamura, N., 1974. Determination of REE, Ba, Fe, Mg, Na and K in carbonaceous and ordinary chondrites. Geochim. Cosmochim. Acta 38, 757-775.

Nelson, D.R., 1997. Compilation of SHRIM U-Pb zircon geochronology data, 1996. Western Australia Geological Survey, Record 1997/2, 189 pp.

Nelson, D.R., 1999. Compilation of geochronology data, 1998. Western Australia Geological Survey, Record 1999/2, 222 pp.

Nelson, D.R., 2000. Compilation of geochronology data, 1999. Geological Survey of Western Australia, Record 2000/2, 251 pp.

Nelson, D.R., 2001. Compilation of geochronology data, 2000. Geological Survey of Western Australia, Record 2001/2, 205 pp.

Nijman, W., De Bruijne, C.H., Valkering, M.E., 1998a. Growth fault control of Early Archaean cherts, barite mounds and chert-barite veins, North Pole Dome, Eastern Pilbara, Western Australia. Precambrian Res. 88, 25-52 (Re-edition in 1999, Precambrian Res. 95, 247-274)

Nijman, W., De Vries, S.T., 2004. Early Archaean crustal collapse structures and sedimentary basin dynamics. In: Eriksson, P.G., Altermann, W., Nelson, D.R., Mueller, W.U., Catuneanu, O. (Eds.), The Precambrian Earth: Tempos and Events. Dev. Precambrian Geol. 12, 139-155.

Nijman, W., Willigers, B.A., Krikke, A., 1998b. Tensile and compressive growth structures: relationships between sedimentation, deformation and granite intrusion in the Archaean Coppin Gap greenstone belt, Eastern Pilbara, Western Australia. Precambrian Res. 88, 83-107 (Re-edition in 1999, Precambrian Res. 95, 277-302).

Oliver, N.H.S., Cawood, P.A., 2001. Early tectonic dewatering and brecciation on the overturned sequence at Marble Bar, Pilbara Craton, Western Australia: dome-related or not? Precambrian Res. 105, $1-15$.

Pidgeon, R.T., Furfaro, D., Kennedy, A.K., Nemchin, A.A., Van Bronswijk, W., 1994. Calibration of zircon standards for the Curtin SHRIMP II. In: Proceedings of the Eighth International Conference on Geochronology, USGS Circular, Berkeley, USA, $251 \mathrm{pp}$.
Thorpe, R.I., Hickman, A.H., Davis, D.W., Mortensen, J.K., Trendall, A.F., 1992a. Constraints to models for Archaean lead evolution from precise zircon $\mathrm{U}-\mathrm{Pb}$ geochronology for the Marble Bar region, Pilbara Craton, Western Australia. In: Glover, J.E., Ho, S.E. (Eds.), The Archaean: Terrains, Processes and Metallogeny, Publication 22. Geology Department and University Extension, The University of Western Australia, 395-407.

Thorpe, R.I., Hickman, A.H., Davis, D.W., Mortensen, J.K., Trendall, A.F., 1992b. U-Pb zircon geochronology of Archaean felsic units in the Marble Bar region, Pilbara Craton, Western Australia. Precambrian Res. 56, 169-189.

Van Haaften, W.M., White, S.H., 1998. Evidence for multiphase deformation in the Archean basal Warrawoona Group in the Marble Bar area, East Pilbara, Western Australia. Precambrian Res. 88, 53-66.

Van Kranendonk, M.J., Hickman, A.H., Collins, W.J., 1998. Comment on "Evidence for multiphase deformation in the Archaean basal Warrawoona group in the Marble Bar area, East Pilbara, Western Australia" by van Haaften, W.M., White, S.H. Precambrian Res. $105,73-78$

Van Kranendonk, M.J., Hickman, A.H., Smithies, R.H., Nelson, D.R., Pike, G., 2002. Geology and tectonic evolution of the Archean North Pilbara Terrain, Pilbara Craton, Western Australia. Econ. Geol. 97, 695-732.

Van Kranendonk, M.J., Hickman, A.H., Williams, I.R., Nijman, W., 2001b. Archaean geology of the East Pilbara granite-greenstone terrane, Western Australia-a field guide. Western Australia Geological Survey, Record 2001/9, 134 pp.

Williams, I.R., 1999. Geology of the Muccan 1:100000 sheet. Western Australia Geological Survey, 1:100000 Geological Series Explanatory Notes, $39 \mathrm{pp}$.

Williams, I.S., Collins, W.J., 1990. Granite-greenstone terranes in the Pilbara Block, Australia, as coeval volcano-putonic complexes; evidence from $\mathrm{U}-\mathrm{Pb}$ zircon dating of the Mount Edgar Batholith. Earth Planet. Sci. Lett. 97, 41-53.

Williams, I.S., Compston, W., Black, L.P., Ireland, T.R., Foster, J.J., 1984. Unsupported radiogenic $\mathrm{Pb}$ in zircon: a cause of anomalously high $\mathrm{Pb}-\mathrm{Pb}, \mathrm{U}-\mathrm{Pb}$ and $\mathrm{Th}-\mathrm{Pb}$ ages. Contrib. Mineral. Petrol. 88, 322-327.

Zegers, T.E., 2004. Granite formation and emplacement as indicators of Archaean tectonic processes. In: Eriksson, P.G., Altermann, W., Nelson, D.R., Mueller, W.U., Catuneanu, O. (Eds.), The Precambrian Earth: Tempos and Events. Dev. Precambrian Geol. 12, 103-118.

Zegers, T.E., Barley, M.E., Groves, D.I., McNaughton, N.J., White, S.H., 2002. Oldest gold: deformation and hydrothermal alteration in the Early Archean shear zone-hosted Bamboo Creek Deposit, Pilbara, Western Australia. Econ. Geol. 97, 757-773.

Zegers, T.E., White, S.H., De Keijzer, M., Dirks, P., 1996. Extensional structures during deposition of the 3460 Ma Warrawoona Group in the eastern Pilbara Craton, Western Australia. Precambrian Res. 80, 89-105. 